\title{
1 Gut-derived bacterial flagellin induces beta-cell inflammation and dysfunction
}

2 Torsten P.M. Scheithauer ${ }^{*}{ }^{1,2}$, Hilde Herrema ${ }^{1}$, Hongbing Yu ${ }^{3}$, Guido J. Bakker ${ }^{1}$,

3 Maaike Winkelmeijer ${ }^{1}$, Galina Soukhatcheva ${ }^{4}$, Derek $\mathrm{Dai}^{4}$, Caixia $\mathrm{Ma}^{3}$, Stefan R.

4 Havik$^{1}$, Manon Balvers ${ }^{1}$, Mark Davids ${ }^{1}$, Abraham S. Meijnikman ${ }^{1}$, Ömrüm Aydin ${ }^{1}$, Bert-

5 Jan H. van den Born ${ }^{1,5}$, Marc G. Besselink ${ }^{6}$, Olivier R. Busch ${ }^{6}$, Maurits de Brauw ${ }^{7}$,

6 Arnold van de Laar $^{7}$, Clara Belzer ${ }^{8}$, Martin Stahl ${ }^{3}$, Willem M. de Vos ${ }^{8}$, , Bruce A.

7 Vallance ${ }^{3}$, Max Nieuwdorp ${ }^{1,2}$, C. Bruce Verchere ${ }^{4}$, Daniël H. van Raalte ${ }^{1,2}$

Affiliations

101 Department of (Experimental) Vascular Medicine, Amsterdam UMC, University of Amsterdam

11 Amsterdam, $1105 \mathrm{AZ}$, The Netherlands

122 Diabetes Center, Department of Internal Medicine, Amsterdam UMC, Vrije Universiteit, Amsterdam,

$131081 \mathrm{HV}$, The Netherlands

143 Department of Pediatrics, Division of Gastroenterology, Hepatology and Nutrition, and BC Children's

15 Hospital Research Institute, Vancouver, British Columbia, V6H 3N1, Canada

164 Departments of Surgery and Pathology and Laboratory Medicine Pathology and Laboratory Medicine, 17 BC Children's Hospital Research Institute, Centre for Molecular Medicine \& Therapeutics, Vancouver, 18 British Columbia V5Z 4H4, Canada

195 Department of Public and Occupational Health, Amsterdam UMC, University of Amsterdam, 20 Amsterdam

216 Department of Surgery, Amsterdam UMC, University of Amsterdam, Cancer Center Amsterdam, the 22 Netherlands

237 Department of Surgery, Spaarne Gasthuis, Hoofddorp, 2134 TM, The Netherlands

248 Laboratory of Microbiology, Wageningen University and Research, 6708 WE, Wageningen, The 25 Netherlands.

269 Human Microbiome Research Program, Faculty of Medicine, University of Helsinki, FI-00014, Helsinki, 27 Finland

29 Correspondence: Torsten P.M. Scheithauer, Department of (Experimental) Vascular Medicine, 30 Amsterdam UMC, Amsterdam, 1105 AZ, The Netherlands, t.p.scheithauer@amsterdamumc.nl 


\section{$31 \quad$ Abstract}

Objective: Hyperglycemia and type 2 diabetes (T2D) are caused by failure of pancreatic beta cells. The role of the gut microbiota in T2D has been studied but causal links remain enigmatic.

36 Design: Obese individuals with or without T2D were included from two independent

37 Dutch cohorts. Human data was translated in vitro and in vivo by using pancreatic 38 islets from C57BL6/J mice and by injecting flagellin into obese mice.

39 Results: Flagellin is part of the bacterial locomotor appendage flagellum, present on gut bacteria including Enterobacteriaceae, which we show to be more abundant in the gut of individuals with T2D. Subsequently, flagellin induces a pro-inflammatory response in pancreatic islets mediated by the Toll-like receptor (TLR)-5 expressed on resident islet macrophages. This inflammatory response associated with beta-cell dysfunction, characterized by reduced insulin gene expression, impaired proinsulin processing and stress-induced insulin hypersecretion in vitro and in vivo in mice.

46 Conclusion: We postulate that increased systemically disseminated flagellin in T2D is a contributing factor to beta cell failure in time and represents a novel therapeutic target.

Keywords

Gut microbiota, type 2 diabetes, inflammation, beta-cell function, flagellin 


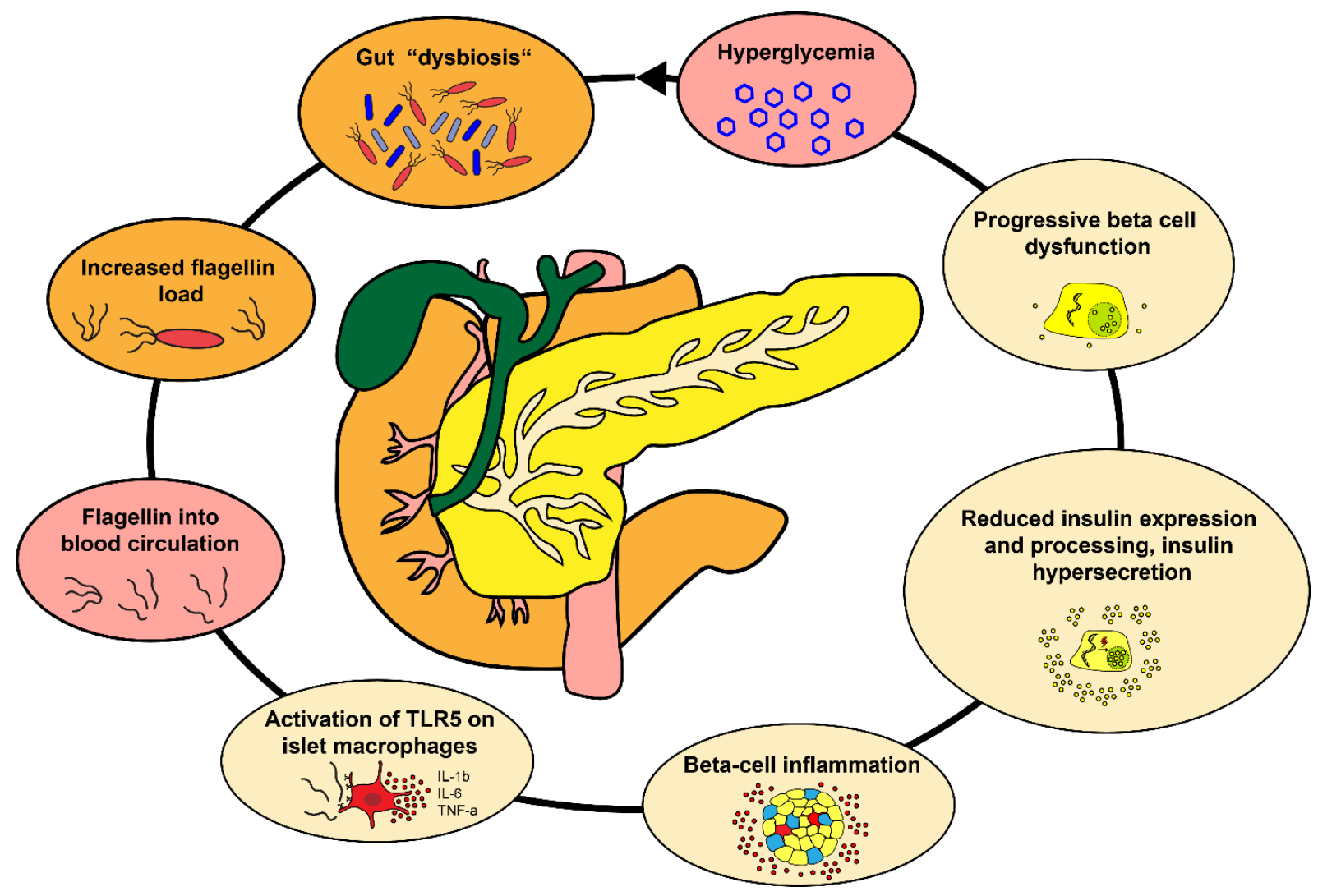




\section{Introduction}

While obesity is linked to insulin resistance, it is failure of pancreatic beta-cells that drives hyperglycemia and subsequent type 2 diabetes (T2D) (Weyer et al., 1999). Although in later stages of T2D insulin secretory rates are lowered, prior to the diagnosis and in earlier phases of the disease, insulin secretion is actually increased (Defronzo, 2009). Insulin hypersecretion, particularly in the fasted state, is considered harmful as it associates with impaired proinsulin processing, insulin secretory stress and depletion of intracellular insulin stores (Pories and Dohm, 2012), further promoting obesity and T2D development (Mehran et al., 2012; Tricò et al., 2018; Weyer et al., 2000). Drivers of hyperinsulinemia are still elusive, but could relate to islet-exposure to excessive nutrients such as carbohydrates and lipids (Erion and Corkey, 2018), as well as a chronic low-grade inflammatory response known to be present in beta cells of people with T2D. In this regard, an influx of pro-inflammatory macrophages in islets of people with T2D has been noted (Donath and Shoelson, 2011; Marchetti, 2016). These macrophages produce pro-inflammatory cytokines such as interleukin (IL)-1 $\beta$ and IL6, which have been associated with insulin hypersecretion (Ellingsgaard et al., 2011; Hajmrle et al., 2016) and beta-cell failure (Donath et al., 2009; Donath and Shoelson, 2011). The triggers that ignite beta-cell inflammation in T2D remain presently unknown.

A recent player in the field of glucose metabolism is the intestinal microbiota. Several cohort (Le Chatelier et al., 2013) and intervention (Kootte et al., 2017) studies have shown an association between gut microbiota composition and T2D incidence (Gurung et al., 2020). People with obesity and T2D often have lower microbial diversity, while showing increased abundance of potentially pathogenic gram-negative bacteria, including Proteobacteria (Ouchi et al., 2011). Mechanistic studies have linked metabolites produced by the gut microbiota to impaired glucose metabolism and a proinflammatory state (Herrema and Niess, 2020). In addition to microbial metabolites, structural components of gram-negative bacteria, such as lipopolysaccharide (LPS), a cell-wall component, and flagellin, part of the bacterial locomotor appendage flagellum, may systemically disseminate in people with T2D (Gomes et al., 2017). These bacterial components activate pro-inflammatory pathways by binding to pattern-recognition receptors (PRRs), including Toll-like receptors (TLRs), expressed on epithelial cells and cells of the innate immune system (Scheithauer et al., 2020). 
87 Here, we provide evidence for a novel pathway in which exaggerated systemic 88 dissemination of gut-derived flagellin in T2D induces a pro-inflammatory state in beta89 cells. This inflammatory response is mediated by flagellin-mediated activation of TLR5 90 expressed on resident islet macrophages. Functionally, the inflammatory response 91 associates with impaired insulin gene expression and proinsulin processing, while 92 inducing hyperinsulinemia. Collectively, these processes markedly reduce insulin 93 stores, which potentially contribute to beta-cell failure over time. 


\section{Results}

Fecal Enterobacter cloacae abundance is associated with hyperglycemia in humans

To investigate the link between beta-cell dysfunction and altered gut microbiota, we analyzed fecal samples for microbiota composition using 16S rRNA sequencing in participants enrolled in the Healthy Life in an Urban Setting (HELIUS) study, a prospective cohort study of the six largest ethnic groups living in Amsterdam, The Netherlands (Deschasaux et al., 2018; Snijder et al., 2017). To prevent confounding effects of ethnic differences on gut microbiota composition (Deschasaux et al., 2018), we analyzed the samples of the 803 Dutch origin participants (Table S1). We observed increased abundance of Gram-negative Enterobacteriaceae in people with T2D as compared to normoglycemic controls (Figure 1A, Table S2), confirming a previous report where Enterobacteriaceae were increased in people with T2D (Qin et al., 2012). We randomly selected 100 people with T2D and compared them to 50 age-, sex- and BMI-matched normoglycemic controls also recruited within the HELIUS cohort (Table S3). We confirmed an enrichment of Enterobacteriaceae in people with T2D using quantitative polymerase chain reaction (qPCR) (Figure 1B). Furthermore, we observed a positive relation with the long-term glucose marker hemoglobin $A 1 C$ (HbA1c) and Enterobacteriaceae abundance (Figure 1C).

Enterobacter cloacae (E. cloacae), a prominent member of the family of Enterobacteriaceae, was previously shown to be associated with impaired glucose tolerance in humans and mice (Fei and Zhao, 2013; Keskitalo et al., 2018). In line with these studies, in our cohort, levels of $E$. cloacae directly increased with deterioration of glucose tolerance (Figure 1D). Further, fecal abundance of $E$. cloacae also positively correlated with $\mathrm{HbA1C}$ (Figure S1A). Thus, as a proof-of-concept, we selected $E$. cloacae for subsequent experiments although we acknowledge that other bacteria of the family Enterobacteriaceae may also associate with glucose (dys)metabolism. 
A
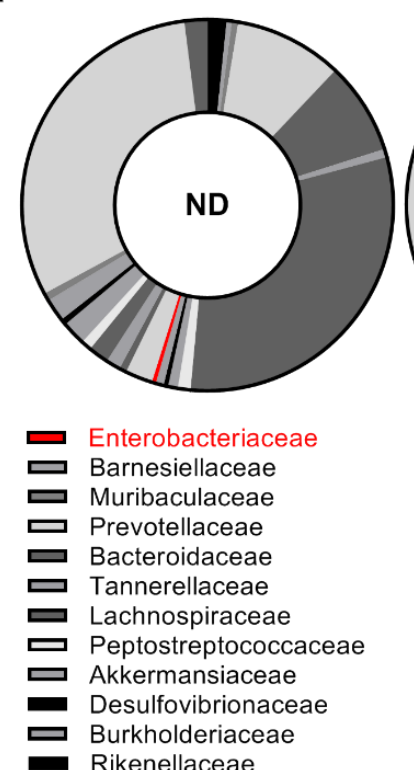

C

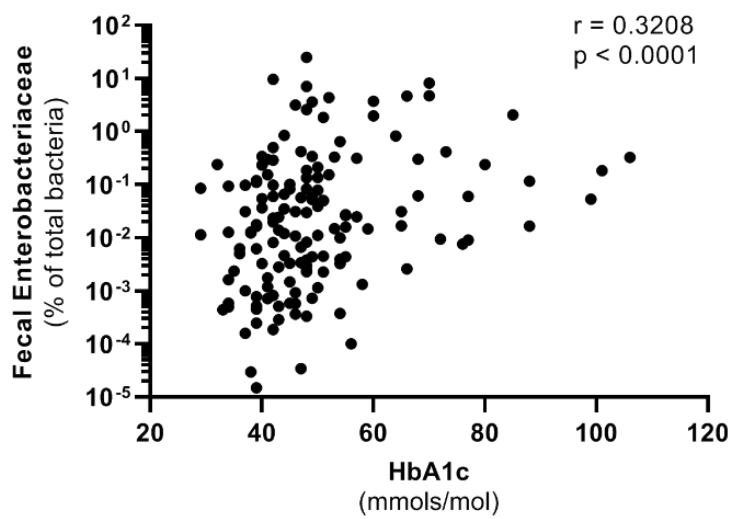

Eggerthellaceae

口 Coriobacteriaceae

Veillonellaceae

Erysipelotrichaceae

- Streptococcaceae

ᄃ Clostridiaceae

ש Ruminococcaceae

ש Other

(mmols/mol)
B

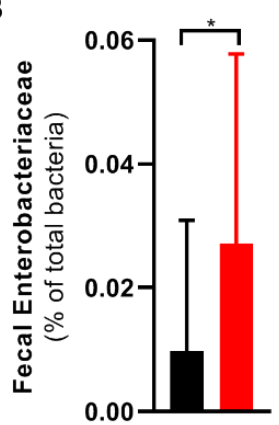

Bifidobacteriaceae

- Acidaminococcaceae

- Christensenellaceae
D

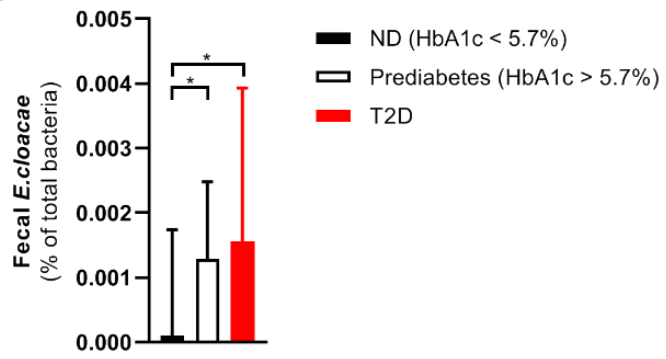

E

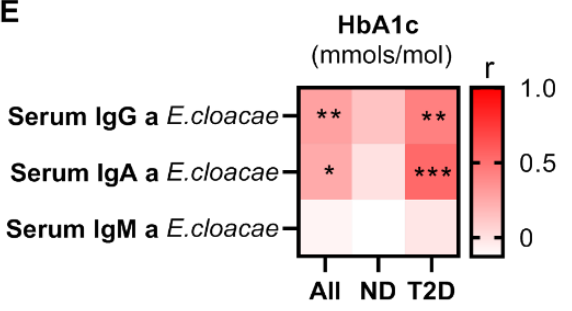

Figure 1. Fecal Enterobacteriaceae is associated with a disturbed glucose tolerance in humans from the HELIUS cohort.

(A) Fecal microbiota composition of people with or without T2D measured via 16S rRNA sequencing (Dutch origin participants, $\mathrm{N}=803, \%$ abundance, median is shown).

(B) Fecal Enterobacteriaceae (qPCR, normalized to total fecal bacterial DNA) is increased in individuals with T2D compared to age-BMI-sex matched healthy controls $(\mathrm{N}=150$, median with $95 \% \mathrm{Cl})$.

(C) Fecal Enterobacteriacaee (qPCR, normalized to total fecal bacteria) positively correlates with the long-term glucose marker $\mathrm{HbA1c}(\mathrm{N}=150)$.

(D) Fecal Enterobacter cloacae (qPCR, normalized to total fecal bacteria) is increased in prediabetes and T2D $(\mathrm{N}=150$, median with $95 \% \mathrm{Cl})$.

136 (E) Correlation analysis of serum antibodies against E. cloacae and $\mathrm{HbA1c}(\mathrm{N}=80)$. Mann Whitney test (B, D) and Spearman correlation (C, E); ${ }^{*} p<0.05,{ }^{* *} p<0.01,{ }^{* * *} p<0.001$. Abbreviations: ND, no diabetes; T2D, type 2 diabetes; HbA1c, Glycated hemoglobin; Ig, immunoglobulin; $\mathrm{Cl}$, confidence interval. 
An immune response against Enterobacter cloacae is associated with hyperglycemia in people with type 2 diabetes

143 An appropriate immune response to opportunistic bacteria is necessary to prevent

144 inflammation (Cullender et al., 2013b). To assess whether there was a systemic immune response to E. cloacae, we assessed plasma antibody levels. We observed a numerical increase in IgG titers against $E$. cloacae in T2D, but otherwise no significant difference between the matched groups with respect to antibodies was noted (Figure S1B). However, there was a positive correlation between $\mathrm{HbA} 1 \mathrm{c}$ levels and systemic IgG and IgA against E. cloacae (Figure 1E), particularly in people with T2D. Further, there was a significant positive correlation between fecal abundance of

151 Enterobacteriaceae and plasma lgG against E. cloacae (Figure S1C). This is 152 suggestive of an immune response against systemically disseminated bacterial 153 components of E. cloacae.

\section{Enterobacter cloacae induces beta-cell inflammation and dysfunction in vitro}

156 Given the link between beta-cell driven hyperglycemia and fecal presence of $E$. cloacae as well as systemic antibodies against E. cloacae, we questioned if E. cloacae would be able to alter pancreatic beta-cell function. We isolated pancreatic islets from C57BL6/J mice fed a conventional chow diet. Islets were co-incubated with $10^{6}$ colony

160 forming units (CFUs) per $\mathrm{mL}$ of heat-inactivated $E$. cloacae or vehicle for 72 hours 161 (Figure 2A-G). We found that beta-cells exposed to heat-inactivated E. cloacae had lower expression of genes involved in insulin production, including the key transcription factors pancreatic duodenal homeobox 1 (PDX1) and MafA (Figure 2A). This lowered expression coincided with a higher inflammatory tone (Figure 2B and 2C), including upregulation of pro-inflammatory cytokines (IL-1 $\beta, I L-6$ and tumor necrosis factor (TNF$\alpha)$, the NLRP3 inflammasome, the macrophage marker F4/80, and TLR2. Interestingly, increased TLR2 expression was previously reported in pancreatic islets of people with diabetes (Ji et al., 2019). Heat-inactivated E. cloacae did not affect cell viability since ATP content was not altered (Figure 2D) (lyer et al., 2009). Incubation with heatinactivated $E$. cloacae also had functional consequences for beta cells. As such, insulin content was markedly reduced after 72 hours of incubation with E. cloacae (Figure

172 2E). In addition, both during low- and high ambient glucose concentrations, beta cells

173 treated with heat-inactivated E. cloacae hypersecreted insulin (Figure 2F). Lastly, E.

174 cloacae treatment increased proinsulin secretion and content as well as 
175 proinsulin/insulin ratios, indicating disturbed proinsulin processing (Figure 2G). We observed similar data in human islets, where heat-inactivated $E$. cloacae lowered MafA expression, increased secreted IL-6, and tended to reduce insulin content (Figure S2A-E). Thus, the profile of increased inflammation, reduced insulin gene expression, impaired proinsulin processing and insulin hypersecretion likely contributes to the detrimental reduction in beta-cell insulin content.

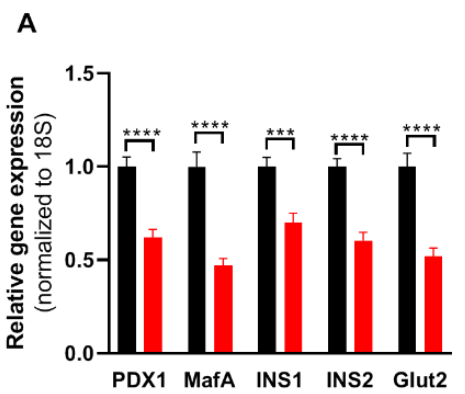

C
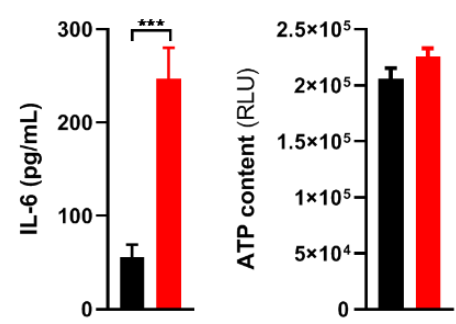

H

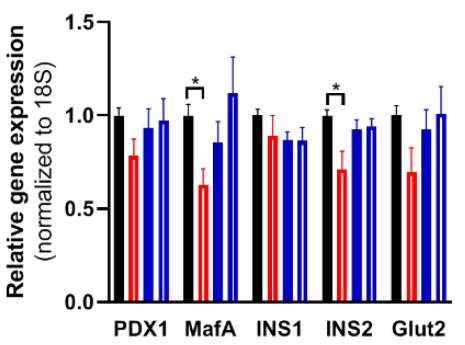

J

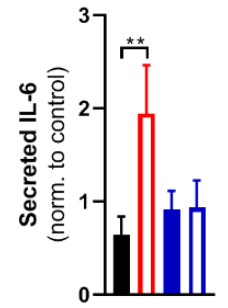

K

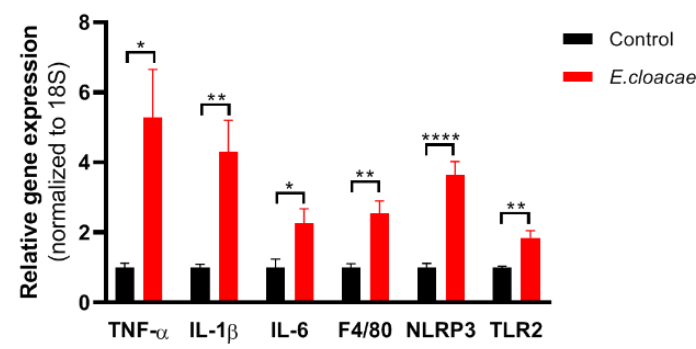

E

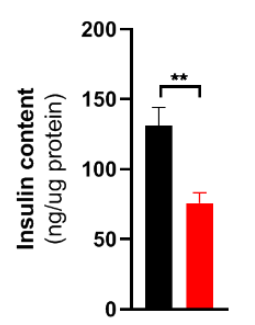

I

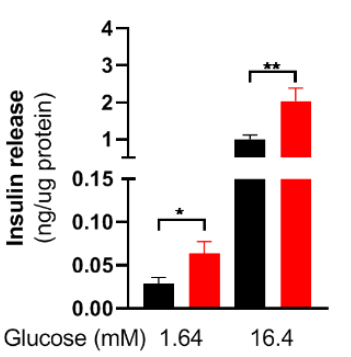

Glucose (mM) $1.64 \quad 16.4$
G
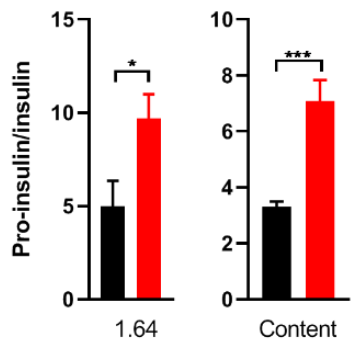
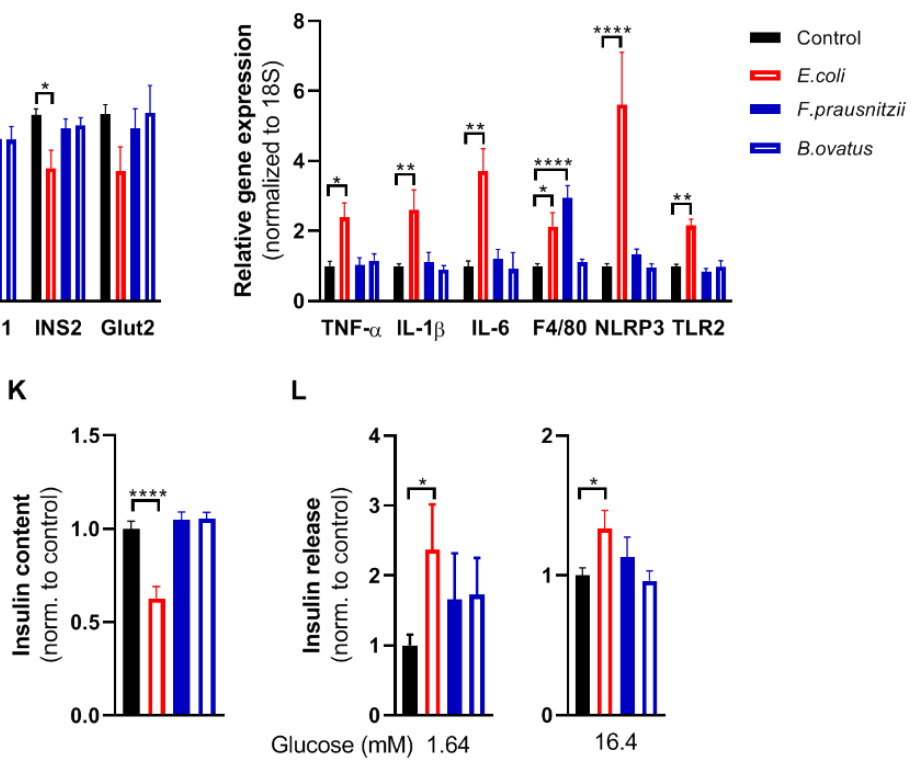
bacteria for $72 \mathrm{~h}$ ( $1 \mathrm{E} 6$ colony forming units $/ \mathrm{mL}$ ). 
(A) Enterobacter cloacae (E. cloacae) reduces expression of beta-cell genes.

(B) E. cloacae increases expression of inflammatory genes in islets.

(C) E. cloacae increases IL-6 secretion by islets.

190

(D) E. cloacae does not reduce ATP content in islets.

(E) E. cloacae reduces insulin content in islets.

(F) E. cloacae increases insulin secretion from islets during low- and high glucose conditions, denoting insulin hypersecretion.

(G) E. cloacae increases the ratio between secreted pro-insulin and insulin, as well as the islet content of pro-insulin relative to insulin, indicating impaired insulin processing.

(H) Escherichia coli, but not Faecalibacterium prausnitzii and Bacteroides ovatus, reduces expression of beta-cell genes

(I) E. coli, but not $F$. prausnitzii and $B$. ovatus increases expression of inflammatory genes in islets.

(J) E. coli, but not $F$. prausnitzii and B. ovatus, induces the release of IL-6 from islets into the media.

(K) E. coli, but not $F$. prausnitzii and $B$. ovatus reduces insulin content in islets.

(L) E. coli, but not $F$. prausnitzii and B. ovatus induces insulin hypersecretion versus controls at both low- and high-glucose conditions.

Data shown are mean \pm SEM. Unpaired t-test $(A, B, C, D, G, H, I, J)$ and Mann Whitney test $(E, F, K, L)$ was used. Significance level: ${ }^{\star} p<0.05,{ }^{* *} p<0.01,{ }^{* * *} p<0.001,{ }^{* * *} p<0.0001$ (mean \pm SEM, 3 representative experiments per panel). Gene expression was normalized using $18 \mathrm{~s}$ as a housekeeping gene. Panels $\mathrm{J}-\mathrm{L}$ were normalized to the control samples since the experiments were performed independently (each bacterium on different days). Abbreviations: PDX1, pancreatic and duodenal homeobox 1; INS1 and INS2, insulin 1 and 2; NLRP3, NACHT, LRR and PYD domains-containing protein 3; TNF- $\alpha$, tumor necrosis factor-alpha; IL-1 $\beta$, Interleukin 1 beta; IL-6, Interleukin 6; TLR2, Tolllike receptor 2; RLU, Relative light unit.

Opportunistic pathogens, but not beneficial bacteria, induce beta-cell inflammation and dysfunction

214 Next, to address whether the E. cloacae-mediated effects were specific to this bacterial species, we repeated the experiments with Escherichia coli (E. coli), another Gramnegative bacterium from the group Enterobacteriaceae (Amar et al., 2011a). E. coli was also increased in T2D participants of the HELIUS study (Figure S1D). In line with our E. cloacae findings, E. coli reduced expression of genes regulating beta-cell maturation and function (Figure $\mathbf{2 H}$ ) and induced an inflammatory response with increased expression of $I L-1 \beta, I L-6, T N F-\alpha$, the $N L R P 3$ inflammasome, $F 4 / 80$ and TLR2 (Figure 2I), and IL-6 protein secretion (Figure 2J). E. coli also reduced cellular insulin content (Figure 2K) and increased insulin secretion (Figure 2L). In order to rule out an effect of bacterial co-incubation per se, we investigated the 224 effects of two bacteria that have been identified as beneficial for the host. These included the Gram-positive Faecalibacterium prausnitzii (Qin et al., 2012) and Gram226 negative Bacteroides ovatus (Zhang et al., 2014), the abundance of which was 227 decreased in people with T2D (Figure S1E and S1F). In contrast to $E$. coli and $E$. 228 cloacae, F. prausnitzii and B. ovatus did not affect islet inflammation, insulin content or 229 insulin secretion (Figure $\mathbf{2 H}-\mathbf{L}$ ). These data indicate that only a subset of bacteria 230 induce an inflammatory response and beta-cell dysfunction. Based on previous mouse 
231 data linking E. cloacae to impaired glucose tolerance (Fei and Zhao, 2013), we decided

232 to further scrutinize the effect of this bacterium on beta-cell function as proof-of233 concept.

Toll-like receptor-2 and Toll-like receptor-4 deletion do not protect against 236 Enterobacter cloacae-induced beta-cell inflammation and dysfunction

237 TLR2 and TLR4 are involved in beta-cell replication (Ji et al., 2019) and have been 238 proposed as two key PRR's that mediate the inflammatory response induced by 239 endogenous and exogenous molecules, the latter including bacterial components such 240 as LPS (Takeuchi et al., 1999). In addition, TLR2 and TLR4 are expressed by 241 pancreatic islet cells (Akira and Takeda, 2004; Giarratana et al., 2004; Wen et al., 242 2004). Therefore, we isolated islets from TLR2 and TLR4 knock out mice and 243 incubated them with E. cloacae (Figure S3). Despite the absence of TLR2, E. cloacae 244 reduced insulin gene expression including MafA (Figure S3A), increased expression 245 of pro-inflammatory cytokines (Figure S3B), increased secreted IL-6 (Figure S3C), 246 and reduced insulin content (Figure S3D).

247 Similarly, TLR4-deficient islet cells were not protected from the effects of E. cloacae, 248 as the expression of beta-cell genes including INS2 was still reduced (Figure S3F). 249 Regarding inflammation, while the expression of $I L-1 \beta, N L R P 3$ inflammasome and $250 F 4 / 80$ was similarly increased by $E$. cloacae in both TLR4 knock out and WT islets, $E$. 251 cloacae incubation did not increase IL-6 expression and secretion (Figure S3G-H). 252 Insulin content was also reduced by E. cloacae incubation (Figure S3I and S3J). 253 Therefore, we concluded that PRRs other than TLR2 and TLR4 likely play roles in E. 254 cloacae-induced beta-cell inflammation and dysfunction. 
A

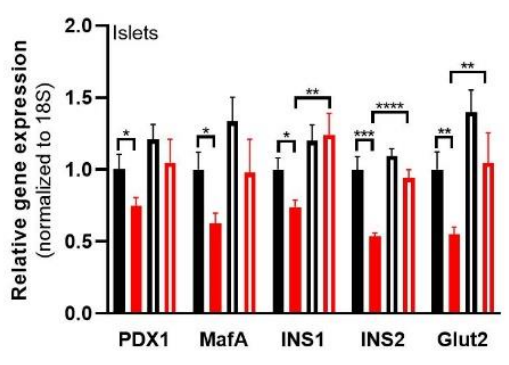

C

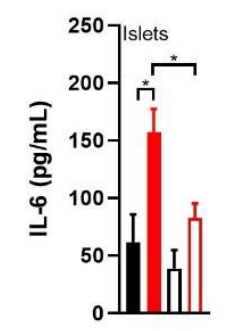

D

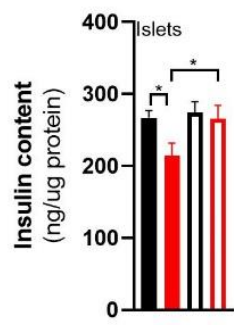

B

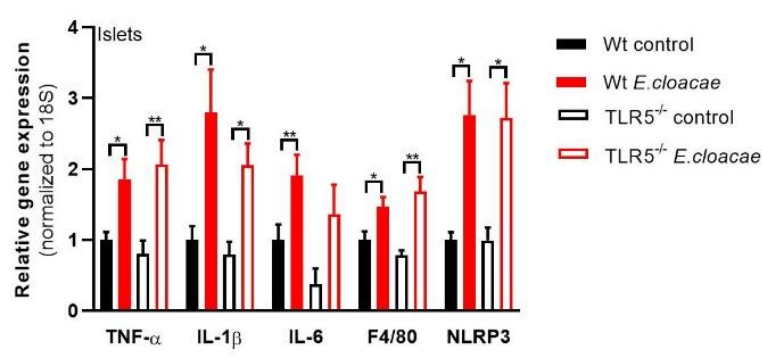

E

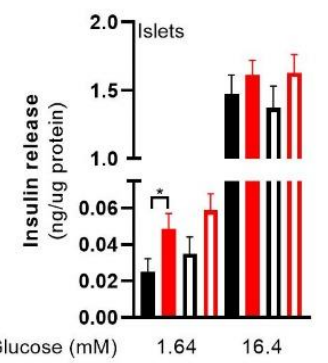

$\mathbf{F}$

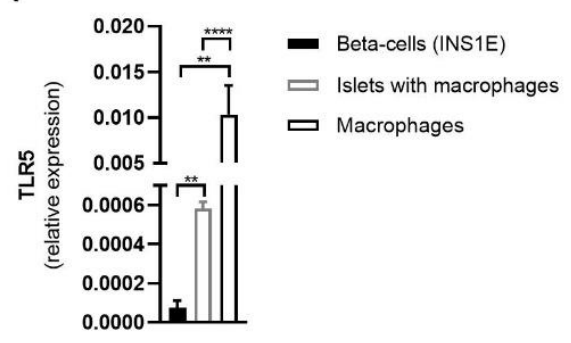

Figure 3. TLR5 is mediating beta cell dysfunction in pancreatic islets

Freshly isolated pancreatic islets from C57BL6J TLR5 $\%$ mice (10 weeks old) were treated with heatinactivated Enterobacter cloacae (1E6 CFUs $/ \mathrm{mL}$ ) for $72 \mathrm{~h}$.

(A) E. cloacae reduces beta-cell gene expression. TLR5 knock out protects from E. cloacae-induced insulin and Glut2 expression loss.

(B) E. cloacae increases beta-cell inflammation. TLR5 knock out does not prevent the effect of $E$. cloacae on pancreatic islet inflammation.

(C) E. cloacae increases beta-cell IL-6 secretion. TLR5 knock out partially protects from E. cloacae induced IL-6 secretion.

(D) E. cloacae reduces beta-cell insulin content. TLR5 knock out protects from E. cloacae-induced insulin content loss.

(E) E. cloacae induces insulin hypersecretion at low glucose condition in wild-type islets, which is not different in TLR5 knock out islets.

(F) Clonal beta cells express very low levels of TLR5 compared to pancreatic islets and macrophages. Data shown are mean \pm SEM. Unpaired t-test was used for statistical analysis (A-C, F) or Mann-Whitney test (D, E). Significance level: ${ }^{*} p<0.05,{ }^{* *} p<0.01,{ }^{* * *} p<0.001,{ }^{* * \star *} p<0.0001$ (mean \pm SEM, 3 representative experiments per panel).

Abbreviations: PDX1, pancreatic and duodenal homeobox 1; INS1 and INS2, insulin 1 and 2; NLRP3, NACHT, LRR and PYD domains-containing protein 3; TNF- $\alpha$, tumor necrosis factor-alpha; IL-1 $\beta$, Interleukin 1 beta; IL-6, Interleukin 6; TLR2, Toll-like receptor 2; TLR5, Toll-like receptor 5.

Toll-like receptor-5 deletion protects against Enterobacter cloacae-induced

\section{beta-cell inflammation and dysfunction}

Several members of Enterobacteriaceae, including E. cloacae, express flagellins as

both virulence and motility factors (De Maayer and Cowan, 2016). Bacterial flagellin is mainly recognized by TLR5 (Yoon et al., 2012), which is expressed by various cell types including epithelial cells and monocytes. We measured the effects of $E$. cloacae in islets from TLR5 knock out mice. TLR5 deletion partially protected islets from betacell dysfunction with preserved expression of insulin genes (Figure 3A). TLR5 
cytokines (Figure 3B), although it did reduce secretion of IL-6 as compared to WT islets (Figure 3C). In addition, in TLR5 knock out islets, E. cloacae did not reduce insulin content (Figure 3D), while similar insulin secretion rates were observed versus WT islets (Figure 3E).

291 To further assess the role of TLR5 in mediating the effects of $E$. cloacae, we co292 incubated WT primary mouse islets with E. cloacae with or without the TLR5 inhibitor TH1020. As TH1020 proved toxic to cells after prolonged incubation, we studied the islets after 6 hours of treatment. In line with TLR5 knock out islets, TH1020 reduced the effects of $E$. cloacae on beta-cell gene expression (partial preservation of PDX1 and MafA expression) and partially offset the E. cloacae-induced expression of $I L-1 \beta$, IL-6 and NLRP3 (Figure S4A-B). Due to the toxic effects of TH1020, particularly on GLUT2 expression, we did not perform glucose stimulated insulin secretion (GSIS).

Macrophages mediate Enterobacter cloacae-induced beta cell inflammation and dysfunction via TLR5 activation

As TLR5 is barely expressed in beta cells (Figure 3F), we concluded that other islet associated cells in the pancreas, particularly resident islet macrophages, could mediate the observed effects of TLR5 activation. Indeed, macrophages as well as pancreatic islets containing macrophages had higher TLR5 expression than pure beta cells (Figure 3F). Macrophages are important for pancreatic islet physiology (Nackiewicz et al., 2020), but can induce beta-cell dysfunction when activated towards a pro-inflammatory phenotype (Ying et al., 2019). We thus depleted macrophages from murine pancreatic islets using clodronate-liposomes (Nackiewicz et al., 2014), followed by $E$. cloacae incubation (Figure 4A-E). Reduction of islet macrophages resulted in the maintenance of beta-cell gene transcription following E. cloacae treatment (Figure 4A). Further, expression of pro-inflammatory cytokines including $I L-1 \beta$ and NLRP3 was reduced (Figure 4B). Particularly, IL-6 secretion was almost abolished (Figure 4C). Insulin content (Figure 4D) and insulin secretion (Figure 4E) were not affected by $E$. cloacae in islets lacking macrophages. In line with a role for islet resident macrophages, we found that pure beta cells (INS1E clonal cell line) did not show inflammation or beta-cell dysfunction following E. cloacae treatment (Figure S5A-D).

318 Further, human islet organoids that consist of pure human endocrine cells, did not show signs of beta-cell dysfunction upon E. cloacae treatment (Figure S5E-F). Further 
evidence for the mediating role of macrophages, E. coli and $E$. cloacae induced an inflammatory response in monocytes, which was less present for $F$. prausnitzii and $B$. ovatus (Figure S5G). The E. cloacae-induced increase in IL-6 secretion could be cell inflammation and dysfunction.

A

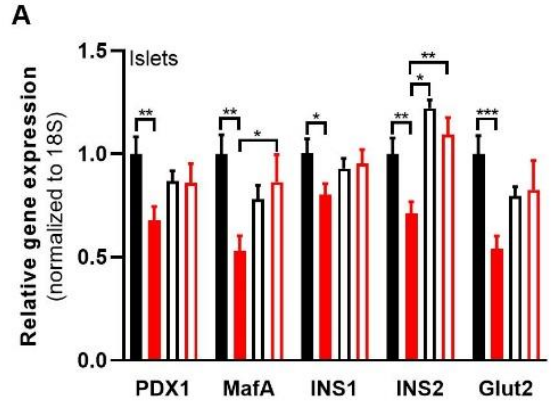

C

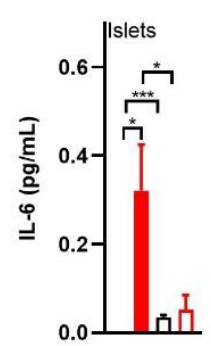

D

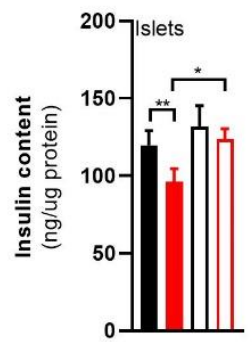

E
B
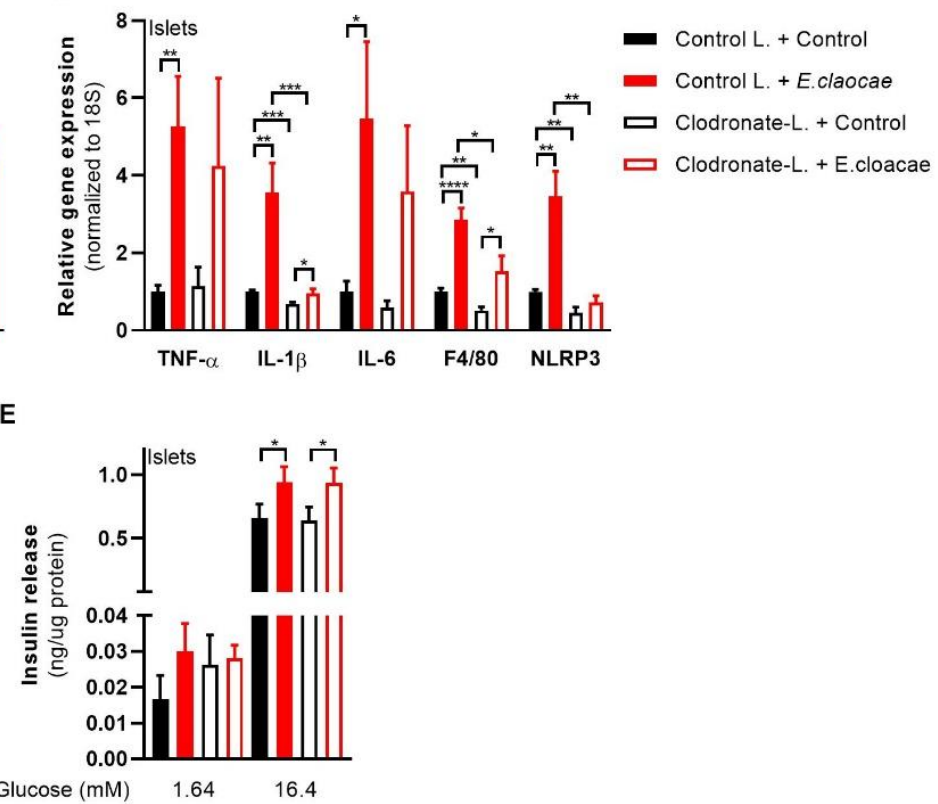

Figure 4. Macrophages mediate beta cell dysfunction in pancreatic islets

Macrophage-depleted islets from wild-type C57BL6J mice were treated with heat-inactivated Enterobacter cloacae (1E6 CFUs/mL) for $72 \mathrm{~h}$.

(A) E. cloacae reduces beta-cell gene expression. Macrophage depletion in pancreatic islets protects from $E$. Cloacae- induced reduction in beta-cell gene expression.

(B) $E$. cloacae increases beta-cell inflammation. Macrophage depletion in pancreatic islets reduces $E$. Cloacae- induced inflammation.

(C) E. cloacae increases beta-cell IL-6 secretion which is prevented by macrophage depletion in pancreatic islets.

(D) E. cloacae reduces insulin content, which is prevented by macrophage depletion.

(E) E. cloacae induces insulin hypersecretion both in WT and in macrophage depleted islets.

Data shown are mean \pm SEM. Unpaired t-test was used for statistical analysis $(A-K)$. Significance level: ${ }^{*} \mathrm{p}<0.05,{ }^{* *} \mathrm{p}<0.01,{ }^{* * *} \mathrm{p}<0.001,{ }^{* * * *} \mathrm{p}<0.0001$ (mean $\pm \mathrm{SEM}, 3$ representative experiments per panel). Abbreviations: PDX1, pancreatic and duodenal homeobox 1; INS1 and INS2, insulin 1 and 2; NLRP3, NACHT, LRR and PYD domains-containing protein 3; TNF- $\alpha$, tumor necrosis factor-alpha; IL-1 $1 \beta$, Interleukin 1 beta; IL-6, Interleukin 6; TLR2, Toll-like receptor 2; TLR5, Toll-like receptor 5.

\section{Bacterial flagellin induces beta-cell inflammation and dysfunction}

Flagellin is the main ligand for TLR5 (Hug et al., 2018) and therefore we hypothesized that this bacterial component could be the driving force behind the E. cloacae-induced phenotype. Indeed, both flagellin and flagellin-bearing E. cloacae activated TLR5 in a 
349 human embryonic kidney (HEK) reporter cell line (Figure 5A), which was dose350 dependently inhibited by the TLR5 inhibitor TH1020. Furthermore, flagellin induced a 351 pro-inflammatory response in human macrophages, which was reduced when co352 incubated with TH1020 (Figure 5B). Additionally, flagellin impaired insulin gene 353 expression (Figure 5C), induced beta-cell inflammation (Figure 5D-E) and reduced 354 insulin content (Figure 5F) while promoting insulin hypersecretion in pancreatic islets 355 (Figure 5G), thus resembling the phenotype induced by E. cloacae.

356 To further dissect the role of flagellin in the beta-cell deteriorating effects mediated by 357 E. cloacae, we generated an E. cloacae-flagellin strain ( $\triangle$ flic $\Delta$ fljB) lacking both fliC and $358 \mathrm{fljB}$. FliC and FljB are two different flagellar filament proteins, and homologous to those 359 expressed by Salmonella enterica (Bonifield and Hughes, 2003). Compared to wild360 type E. cloacae, E. cloacae $\Delta$ fliC $\Delta$ fljB did not suppress beta-cell gene transcription 361 (Figure $5 \mathbf{H}$ ). In addition, expression of inflammatory cytokines and secreted IL-6 were 362 lower in islets exposed to the $\Delta f l i C \Delta f l j B$ strain as compared to islets exposed to wild363 type E. cloacae (Figure 5l-J). Islets had higher insulin content after incubation with the $364 \Delta$ fliC $\triangle$ fljB strain as compared to wild-type E. cloacae (Figure 5K). Finally, the $365 \Delta$ fliC $\Delta$ fljB strain did not induce fasting insulin hypersecretion (Figure 5L). Collectively, 366 these results strongly suggest that flagellin, as part of the flagellum carried by bacteria 367 belonging to Enterobacteriaceae, plays a pivotal role in beta-cell inflammation and 368 beta-cell dysfunction via TLR5 activation on resident islet macrophages. 
A

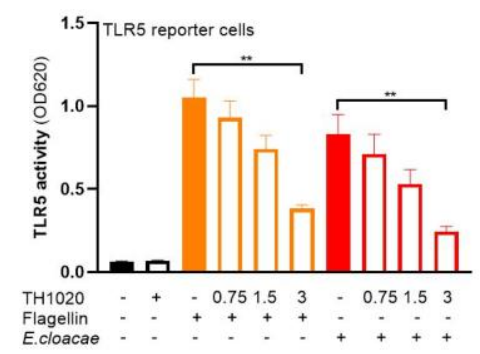

C

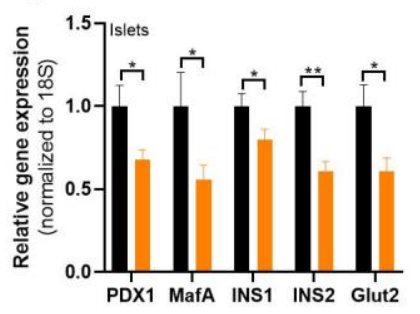

E

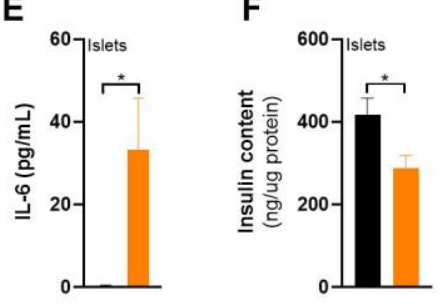

H

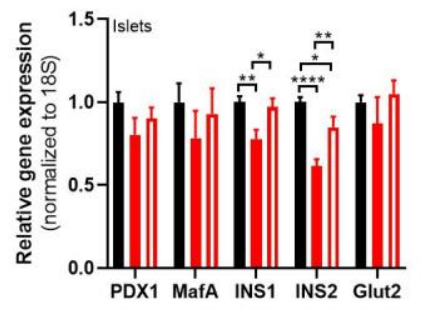

J

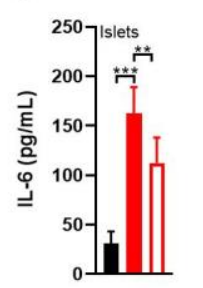

$\mathrm{K}$

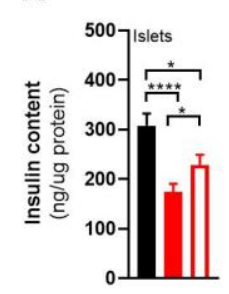

B

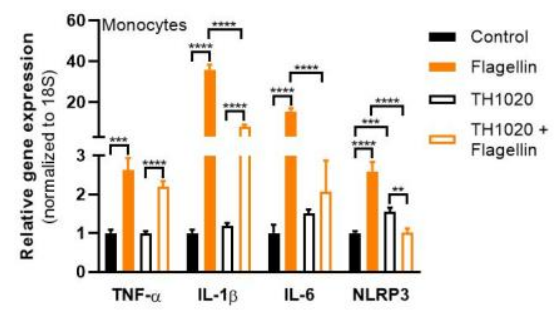

D

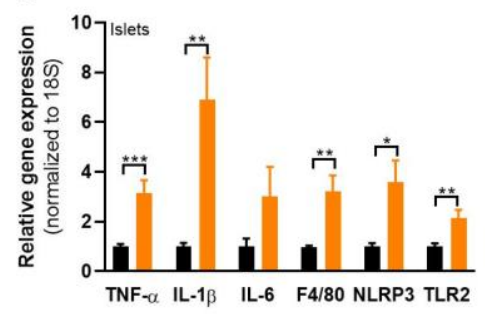

6

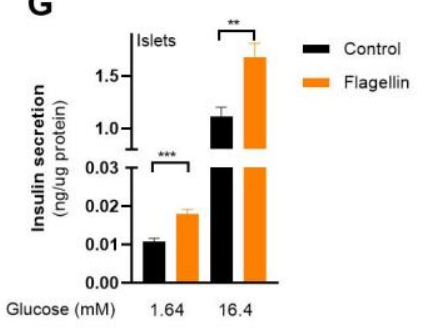

I

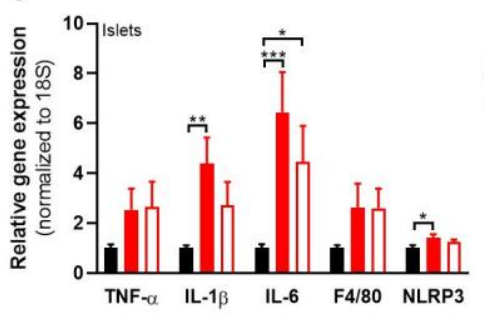

L

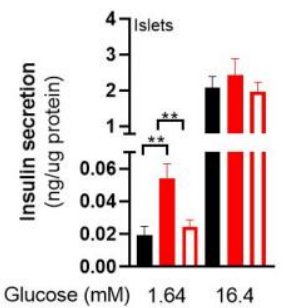
were incubated with flagellin $(100 \mathrm{ng} / \mathrm{mL})$, E.cloacae $(1 \mathrm{E} 6 \mathrm{CFUs} / \mathrm{mL})$ or flagellin knock out E.cloacae $(\mathrm{H}-\mathrm{L})$.

(A) Flagellin and E. cloacae activate TLR5 in HEK reporter cell line. TLR5 inhibitor TH1020 inhibits receptor activity dose-dependently (in $\mu \mathrm{M}$ ).

(B) Flagellin increases expression of inflammatory genes in macrophages, which is reduced by TLR5 inhibitor TH1020 (3 $\mu \mathrm{M})$.

(C) Flagellin reduces beta-cell gene expression.

(D) Flagellin increases expression of inflammatory genes in islets.

(E) Flagellin increases secreted IL-6 by islets. 
(F) Flagellin reduces insulin content in islets.

(G) Flagellin induces insulin hypersecretion in islets.

(H) E. cloacae reduces beta-cell gene expression. Knock out of flagellin in E. Cloacae partially protects against this loss of gene expression.

(I) E. cloacae induces beta-cell gene inflammation. Knock out of flagellin in E. Cloacae partially protects against this inflammatory response.

(J) E. cloacae stimulates IL-6 secretion by islets. Knock out of flagellin in E. Cloacae partially protects against this enhanced IL-6 release.

(K) E. cloacae reduces beta-cell insulin content. Knock out of flagellin in E. Cloacae protects against this loss of insulin stores.

(L) E. cloacae induces insulin hypersecretion at low glucose. Knock out of flagellin in E. Cloacae protects against this impaired secretory response.

Data shown are mean \pm SEM. Unpaired t-test $(A-E, H-J)$ or Mann-Whitney $(F, G, K, L)$ test was used for statistical analysis: ${ }^{*} p<0.05,{ }^{* *} p<0.01,{ }^{* * *} p<0.001,{ }^{* * * *} p<0.0001$

Abbreviations: INS1 and INS2, insulin 1 and 2; NLRP3, NACHT, LRR and PYD domains-containing protein 3; IL-1 $\beta$, Interleukin 1 beta; IL-6, Interleukin 6; TLR, toll like receptor; $\Delta$ fliC $\Delta$ fljB, flagelline genes knock out.

\section{Flagellin treatment augments insulin secretion in mice}

To translate beta-cell dysfunction inducing effects of flagellin to an in vivo situation, we injected flagellin intraperitoneally into diet-induced obese (DIO) C57BL6J mice twice weekly for four weeks (Figure 6A). Flagellin injection did not alter body weight or fasting glucose (Figure 6B-C). However, flagellin-treated mice had lower glucose levels during an intraperitoneal glucose tolerance test compared to the placebo group (Figure 6D-E), which was driven by increased insulin secretion (Figure 6F) since insulin sensitivity did not differ between groups (Figure 6G-H). Similar to the in vitro experiments, there was a higher inflammatory tone in the pancreas of flagellin-treated mice as shown by higher $I L-1 \beta$ expression (Figure $6 \mathrm{I}$ ) and a trend towards more inflammation in pancreatic islets isolated from flagellin-treated mice (Figure 6K).

411 Insulin content of isolated islets did not differ between groups, while insulin release 412 tended to increase during glucose-stimulated insulin secretion ex vivo in islets isolated 413 form the flagellin group (Figure $\mathbf{6} \mathbf{J}-\mathbf{M}$ ). These results suggest that flagellin-induced 414 transcriptional and functional alterations in beta-cell function, as observed in vitro, could be largely replicated in vivo in a mouse model. 


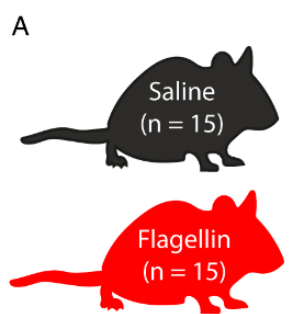

B

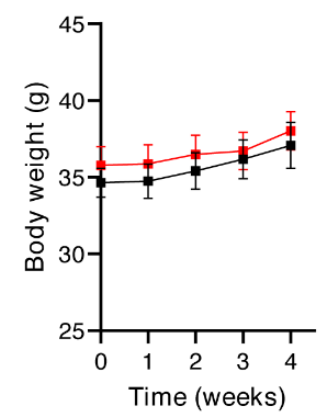

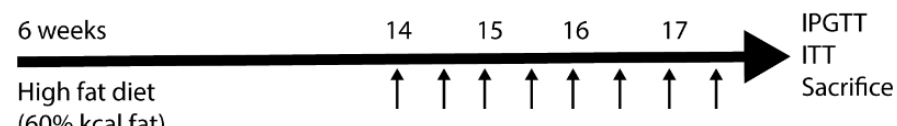

$(60 \%$ kcal fat $)$

C
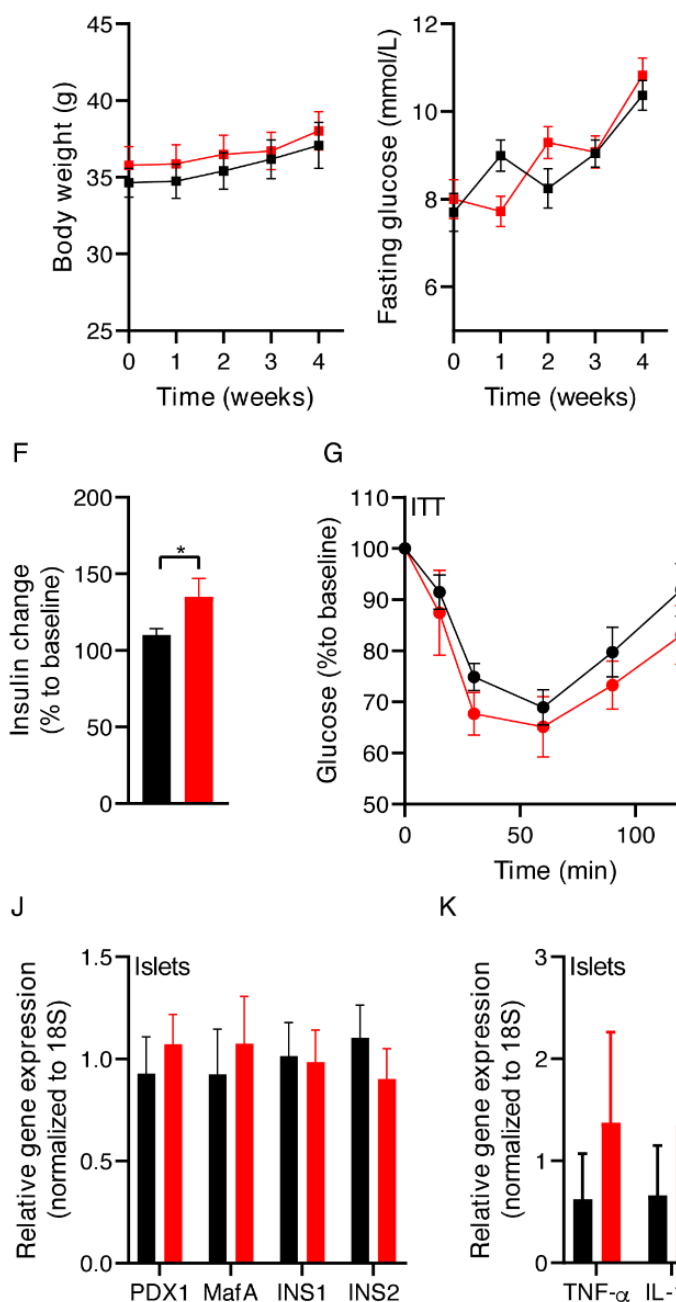

$\mathrm{G}$

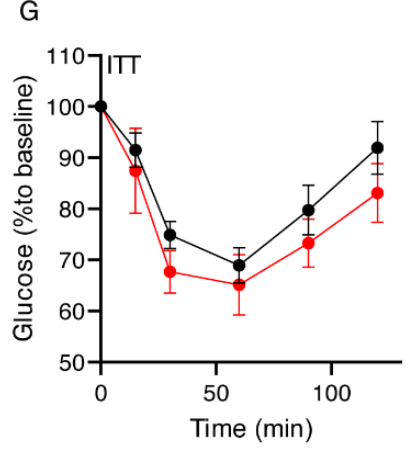

$\mathrm{K}$
IP Injections
$\mathrm{H}$

I

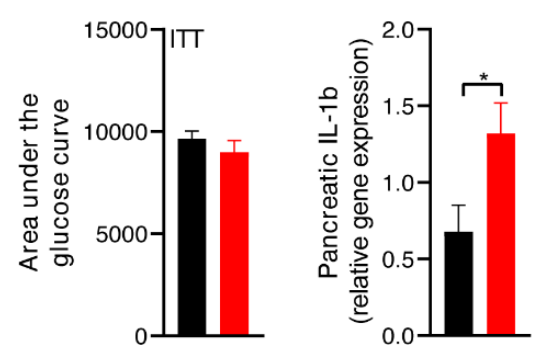

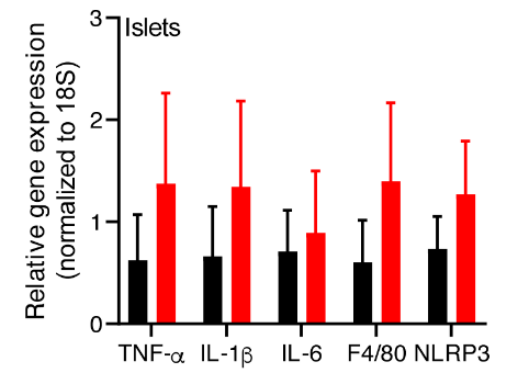

$\mathrm{L}$

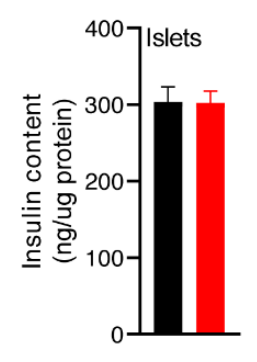

(2x per week, $100 \mathrm{uL}$, 1 ug flagellin/mouse)

D

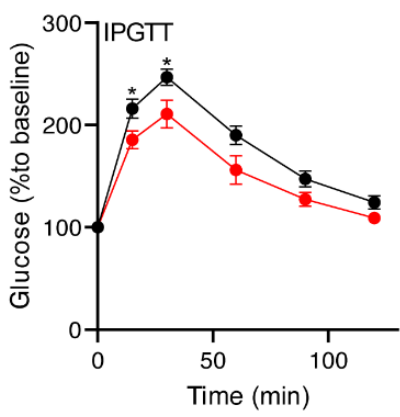

E

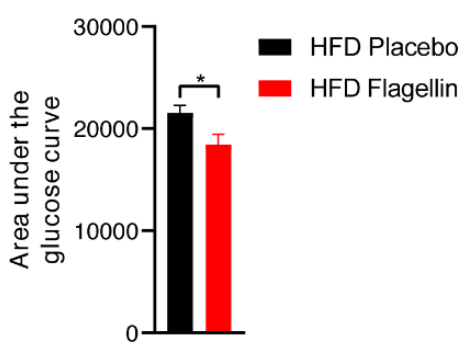

M

Figure 6. Flagellin injection in mice disturbs glucose tolerance

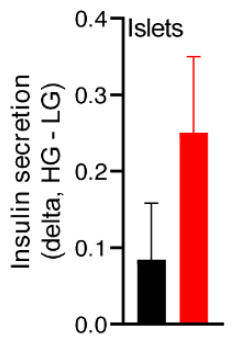

(A) Six-week old mice were fed a high fat diet (60\%kcal fat) for 12 weeks. In the last 4 weeks of the diet, the mice were injected with either $1 \mathrm{ug}$ flagellin in $100 \mathrm{uL}$ saline or saline alone twice weekly.

421 (B) Flagellin injections do not change the body weight.

(C) Flagellin injections do not change fasting plasma glucose concentrations.

(D, E) Flagellin-injected mice have improved glucose tolerance compared to placebo-treated mice (lower area under the glucose curve).

(F) Fold change (15 min to baseline) of plasma insulin is greater in flagellin-treated mice compared to placebo $(n=10)$.

$(\mathrm{G}, \mathrm{H})$ Insulin sensitivity is not affected by flagellin injection $(0.75 \mathrm{IU} / \mathrm{kg})$. The relative change in glucose

430 (I) Flagellin increases pancreatic IL-1b expression.

(J) Pancreatic islets were isolated from flagellin or saline treated mice, rested for 3 hours and gene expression was measured. Flagellin injections do not affect beta-cell gene expression $(n=5)$.

(K) Flagellin injection numerically increases markers of beta cell inflammation $(n=5)$.

(L) Insulin content was measured after islets were treated first with low glucose, followed by high glucose for $1 \mathrm{~h}$ each. Flagellin injection does not affect insulin content $(n=5)$ 
(M) Glucose stimulated insulin secretion was performed on islets and insulin release was measured at low as well as high glucose condition for $1 \mathrm{~h}$ each. Flagellin injection numerically increases insulin release from beta cells $(n=5)$

Data shown are mean \pm SEM. Unpaired t-test $(E, F, I)$ or Šídák's multiple comparisons test (D) was used ${ }^{*} p<0.05,{ }^{* *} p<0.01,{ }^{* * *} p<0.001,{ }^{* * * *} p<0.0001$.

Abbreviations: INS1 and INS2, insulin 1 and 2; NLRP3, NACHT, LRR and PYD domains-containing protein 3; IL-1 $\beta$, Interleukin 1 beta; IL-6, Interleukin 6; TNF- $\alpha$, tumor necrosis factor-alpha; ITT, insulin tolerance test, IP, intraperitoneal; IPGTT, IP glucose tolerance test; HG, high glucose; LG, low glucose.

\section{Systemic flagellin dissemination relates to beta-cell dysfunction in humans}

Fecal flagellin has been reported to be increased in obese people compared to lean controls (Tran et al., 2019). Similarly, we observed that obese mice had a higher flagellin load compared to lean mice (Figure S6). We predicted fecal flagellin gene abundance in the 150 HELIUS participants by inference from 16S rRNA profiles using PICRUSt (Table S3, Figure 7A). Fecal flagellin gene abundance was increased in T2D (Figure 7B). Next, we measured bacterial flagellin in the human blood circulation of the HELIUS cohort. While there was no difference between the matched obese groups, we did observe a positive correlation between serum flagellin load and $\mathrm{HbA} 1 \mathrm{c}$ in T2D (Figure 7C). We hypothesized that increased flagellin reaches the circulation following a meal, which was previously shown to drive translocation of endotoxins (Ghoshal et al., 2009). We therefore measured postprandial plasma flagellin, C-peptide and plasma glucose in 80 matched participants of our bariatric surgery cohort (Van Olden et al., 2021) comprising obese normoglycemic and obese T2D people during a mixed-meal test (MMT) (Figure 7A, Table S4). C-peptide was chosen as it reflects insulin secretion rates and is not affected by potential differences in clearance by the liver, as is the case for plasma insulin concentrations. The MMT additionally allowed us to study the relationship between meal-induced flagellin and beta-cell response to an MMT. Participants with T2D had hyperglycemia following the MMT (Figure 7D-E) and lower C-peptide concentrations (Figure 7F-G) compared to normoglycemic humans with obesity. In both groups, flagellin increased during the MMT (Figure 7H). Postprandial area under the curve (AUC) for flagellin correlated with AUC C-peptide (Figure 7l), highlighting the link between bacterial flagellin and beta-cell insulin secretion in human beta-cell physiology. 
A

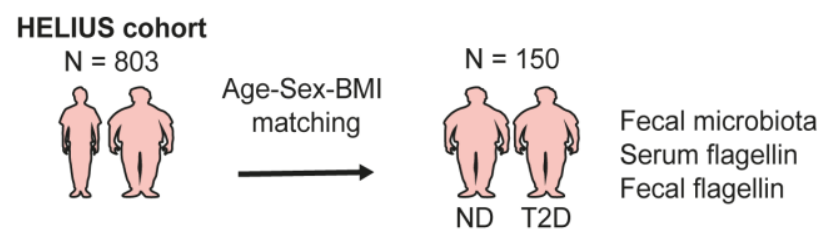

BARIA cohort

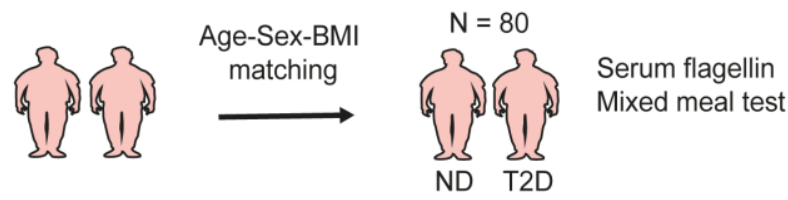

B

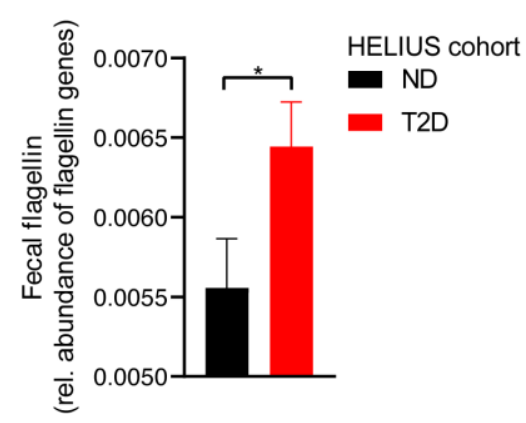

C

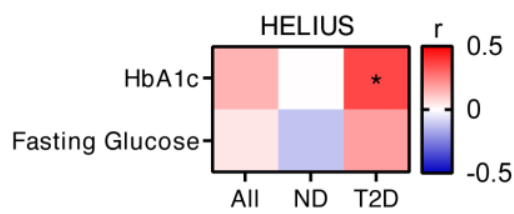

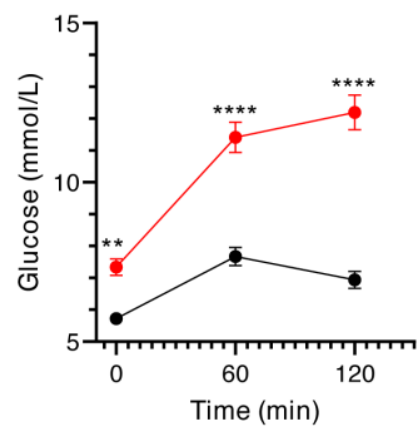

$\mathrm{H}$

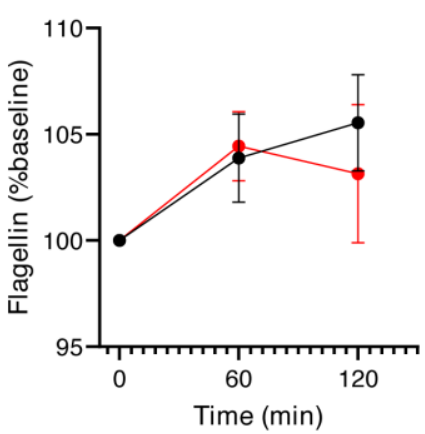

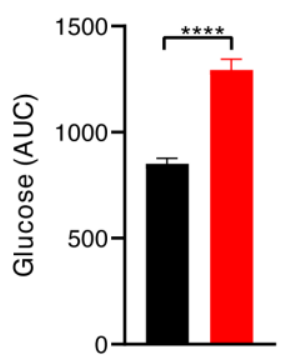

$\mathrm{F}$

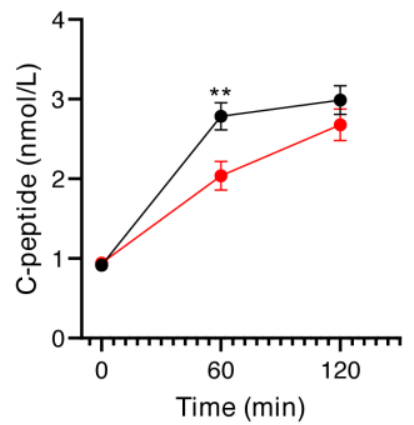

471 (A) 150 people were randomly selected from the HELIUS cohort (Snijder et al., 2017). Participants 472 with T2D were matched with normoglycemic controls according to age, sex and BMI. In addition, 80 participants were selected from our bariatric surgery cohort (Van Olden et al., 2021).

(B) Fecal flagellin genes are increased in T2D, as inferred from 16S rRNA gene profiles (HELIUS).

(C) Serum flagellin positively correlates with HbA1c in people with T2D (HELIUS). 
(F, G) Plasma C-peptide concentrations during a mixed meal test (MMT) (BARIA). C-peptide levels are higher in the obese normoglycemic controls versus T2D participants.

480 (H) Serum flagellin increases during a mixed meal test (BARIA).

481 (I) A positive correlation between serum flagellin area under the curve (AUC) and plasma C-peptide AUC during the MMT (BARIA) exists.

483 Data shown are mean \pm SEM. Unpaired t-test $(B, E, G)$, Spearman correlation (C, I) and Šídák's 484 multiple comparisons test (D, F) was used: ${ }^{*} p<0.05$, ${ }^{* *} p<0.01,{ }^{* * *} p<0.001,{ }^{* * * *} p<0.0001$.

485 Abbreviations: HELIUS, Healthy Life in an Urban Setting; AUC, Area under the curve. 
486

487

488

489

490

491

492

493

494

495

496

497

498

499

500

501

502

503

504

505

506

507

508

509

510

511

512

513

514

515

516

517 517

\section{Discussion}

In this study, we reveal a novel pathway by which flagellin, a structural component of notably Gram-negative bacteria residing in the gut, systemically disseminates following food ingestion. In pancreatic islets that are abundantly vascularized (Brissova and Powers, 2008), we propose that flagellin activates the innate immune system and induces an inflammatory response following binding to TLR5 receptors expressed by resident islet macrophages. This leads to beta-cell dysfunction, characterized by impaired insulin gene expression, impaired insulin processing, insulin hypersecretion/hyperinsulinemia and reduced insulin cell content. This study provides a new insight into the link between gut microbiota composition and T2D.

Beta-cell dysfunction is the key abnormality that leads to the development of hyperglycemia and T2D. Beta-cell dysfunction is characterized by inappropriate fasted or postprandial insulin secretion, which can either be excessive or insufficient, upon exposure to glucose or other nutrients (Johnson, 2021). While in the later stages of the disease insulin secretion rates are hampered, in people with prediabetes or early after diagnosis of T2D, hyperinsulinemia is often observed (Weyer et al., 2001). The role of hyperinsulinemia in T2D development has received ample attention. While initially reported to be a response against obesity-related insulin resistance, research has indicated that increased insulin secretion can develop in the absence of insulin resistance implying primary beta-cell pathology (Staimez et al., 2013). Importantly, hyperinsulinemia per se has negative effects.

Induction of hyperinsulinemia has been shown to promote obesity (Mehran et al., 2012), while prevention of hyperinsulinemia by pancreas-specific genetic knock out of insulin expression prevented obesity, improved insulin sensitivity and did not result in overt hyperglycemia (Mehran et al., 2012; Templeman et al., 2015; Templeman et al., 2017). With respect to the pancreatic islets, a chronic demand on beta cells to produce insulin is detrimental. As such, a prolonged increase in insulin secretory rates have been related to endoplasmic reticulum (ER) stress, depletion of intracellular insulin stores and beta-cell apoptosis (Hasnain et al., 2014). Pancreatic islets from individuals with T2D have lower insulin content compared to healthy controls (Cantley and Ashcroft, 2015; Henquin, 2019; Rahier et al., 2008; Rosengren et al., 2012). In mice, hyperglycemia leads to insulin content loss (Brereton et al., 2014). Reversibly, 
518 strategies that induce beta-cell rest are linked to improved beta-cell function over time

519 (van Raalte and Verchere, 2017).

520 Current evidence relates overnutrition of carbohydrates and non-esterified fatty acids 521 to beta-cell dysfunction (Esser et al., 2020). Another factor concerns a low-grade inflammatory response (Hajmrle et al., 2016). Beta-cell inflammation is a known hallmark of islets in people with T2D (Boni-Schnetzler and Meier, 2019) and a central role in this regard has been proposed for islet macrophages (Ehses et al., 2007). Macrophages are essential for normal beta-cell function and physiology (Nackiewicz et al., 2020), however, macrophages with a pro-inflammatory phenotype have been linked to beta-cell dysfunction (Nackiewicz et al., 2014). Triggers for activation of proinflammatory macrophages are uncertain but may involve hyperglycemia (Maedler et al., 2001), dyslipidemia (Igoillo-Esteve et al., 2010) and human islet amyloid polypeptide (hIAPP) (Westwell-Roper et al., 2014).

Here, we show an infectious stimulus triggering inflammation and beta-cell dysfunction: flagellin derived from intestinal microbiota. While Gram-negative bacteria are known to produce the canonical flagellin which is studied here, several other intestinal Firmicutes species are motile and have been described to contain flagella, including several Roseburia, Clostridium, and Lactobacillus spp (Dehoux et al., 2016; MM et al., 2015; Tamanai-Shacoori et al., 2017). However, the flagellins of these latter, Gram-positive bacteria have not been well characterized and some are glycosylated resulting in attenuated TLR5 signaling efficiency (Kajikawa et al., 2016).

A first link towards flagellin came from the observation that in a large cohort the fecal abundance of the family of Enterobacteriaceae, specifically E. cloacae, was increased in people with T2D and that the fecal abundance of Enterobacteriaceae and E. cloacae correlated with glucose intolerance in humans. Administration of

E. cloacae by oral gavage to mice fed a high-fat diet has previously been shown to induce glucose intolerance (Fei and Zhao, 2013). A proposed mechanism by which gut microbiota may influence host metabolism is by escaping immune control and translocating to extra-

547 intestinal tissues (Amar et al., 2011a; Amar et al., 2011b). While this has been shown 548 for adipose tissue (Massier et al., 2020; Udayappan et al., 2017), translocation of 549 intestinal bacteria into the pancreas was also suggested to trigger the influx of immune cells and islet inflammation (Thomas and Jobin, 2020). In patients undergoing 
pancreatoduodenectomy, pancreatic fluid contained bacterial DNA, with a similar composition, density and diversity as bile and jejunal fluid (Rogers et al., 2017), suggesting direct translocation from the small intestine into pancreatic juice. Others also suggest a bacteriome (Riquelme et al., 2019) and mycobiome (Aykut et al., 2019) in pancreatic tissue of cancer patients. In line with these data, we observe a correlation between systemic antibodies against E. cloacae and hyperglycemia, which may suggest translocation of at least parts of this bacteria to extraintestinal sites. Nevertheless, translocation of whole bacteria remains rather controversial (Scheithauer et al., 2020) since there are major challenges related to the sequencing of small amounts of bacterial DNA in extraintestinal tissues (de Goffau et al., 2019).

Heat-inactivated E. cloacae induced a detrimental beta-cell phenotype with insulin hypersecretion, induction of ER stress markers (elevated $\mathrm{PI} / \mathrm{I}$ ratio), inflammation and reduced beta-cell insulin content. We show that deletion of TLR5, of which flagellin is the dominant ligand, on resident islet macrophages protected against the effects of the flagellum-bearing E. cloacae. Flagellum is a virulence factor that enables bacteria to move within the intestine and even adhere to the intestinal wall, a process called encroachment (Haiko and Westerlund-Wikström, 2013; Tran et al., 2019). Flagellin fully reproduced the beta-cell phenotype of E. cloacae. A causal role for flagellin was observed in $E$. cloacae with flagellin knock out, where the effects on inflammation, hypersecretion and reduced insulin content were strongly diminished. Strengthening the role of flagellin, mice that were injected with flagellin exhibited a similar beta-cell phenotype.

In line with our previous work (Scheithauer et al., 2021), we observed an increment in plasma flagellin concentrations following a meal in the current cohort. This indicates that flagellin, like the widely studied LPS, may translocate after food ingestion. Importantly, flagellin is able to pass the epithelial barrier (Gewirtz et al., 2001) and is a potent stimulus of the mucosal immune response (Cullender et al., 2013a; Vijay-Kumar and Gewirtz, 2009). Plasma flagellin levels also positively correlated with $\mathrm{HbA1c}$ in our cohort, while the meal-related flagellin increment associated with higher C-peptide release in obese humans with or without diabetes. 
undergoing pancreatic surgery for benign lesion. We collected five biopsies of the head of the pancreas. Recent antibiotics use (<3 months) was an exclusion criterion (Table S5). While it was technically not possible to measure flagellin in these biopsies due to interference of the pancreatic enzymes with the flagellin assay, we observe the presence of antibodies against flagellin, supporting the notion that the wellvascularized pancreatic islets are exposed to flagellin (Figure S7). A previous study indicated that a functional immune response is essential to control flagellin expression bacteria (Cullender et al., 2013a), which seems to be reduced in obese humans (Tran et al., 2019).

We acknowledge a number of limitations of this study. First, although the concept of translocation of flagellin to the systemic circulation seems to be plausible to explain beta-cell inflammation (Thomas and Jobin, 2020), we can only speculate if bacterial flagellin is transported via the blood circulation towards the pancreas. More sensitive methods are necessary to quantify small amounts of bacterial components such as flagellin in extra-intestinal tissues (Scheithauer et al., 2020; Tran et al., 2019). Second, we provide evidence that people with T2Ds have a higher fecal and circulating flagellin load compared to normoglycemic individuals, with flagellin loads correlating with hyperglycemia. However, such a correlation does not show causation. Future research should evaluate whether reducing intestinal or systemic flagellin load will improve betacell function and can reduce diabetes incidence. Third, the concept of insulin hypersecretion and its linked to low-grade inflammation needs further validation; as such, studies that show the benefits of reducing insulin hypersecretion are currently scant. In addition, a moderate inflammatory response has been suggested to be beneficial in stimulating insulin release (Ying et al., 2020), although the effects of prolonged inflammation may have different effects.

612 Together, we present a novel pathway linking bacterial flagellin from the Gram613 negative $E$. cloacae in a TLR5-macrophage-dependent manner to beta-cell 614 inflammation and beta-cell dysfunction, suggesting a new mechanism linking gut 615 microbiota and T2D prevalence and opening up potential avenues for novel therapies. 
617

618

619

620

621

622

623

624

625

626

627

628

629

630

631

632

633

634

635

636

637

638

639

640

641

642 M.G.B and O.R.B. provided pancreatic biopsies. G.M.D.T., G.J.B. and W.M.V. aided 643 with the writing. B.J.H.B. conducted the HELIUS cohort. B.A.V., M.N., H.H. and C.B.V. 644 supervised the project. D.H.R. developed the theory and supervised the project.

\section{Acknowledgments}

This study was funded by Diabetes Fonds (Application number: 2015.81.) and Marie Skłodowska-Curie Actions (Call H2020-MSCA-IF-2015). CBV was supported by CIHR project grant PJT-165943. M.N. is supported by a personal ZONMW VICI grant 2020 [09150182010020]. B.A.V. is the Children with Intestinal and Liver Disorders (CH.I.L.D) Foundation Chair in Pediatric Gastroenterology. The HELIUS study is conducted by the Amsterdam University Medical Centers, location AMC and the Public Health Service of Amsterdam. Both organisations provided core support for HELIUS. The HELIUS study is also funded by the Dutch Heart Foundation, the Netherlands Organization for Health Research and Development (ZonMw), the European Union (FP-7), and the European Fund for the Integration of non-EU immigrants (EIF). We are most grateful to the participants of the HELIUS study and the management team, research nurses, interviewers, research assistants and other staff who have taken part in gathering the data of this study. The study reported here was additionally supported by (an) additional grant(s) from Dutch Heart Foundation: 2010T084 (K Stronks), ZonMw: 200500003 (K Stronks), European Union (FP-7): 278901 (K Stronks), European Fund for the Integration of non-EU immigrants (EIF): 2013EIF013 (K Stronks). $\mathrm{HH}$ is supported by a Senior Fellowship of the Dutch Diabetes Research Foundation (2019.82.004).

\section{Author contributions}

T.P.M.S. performed the experiments and prepared the manuscript. M.W. performed experiments. S.R.H., G.S., M.S. and D.D. assisted with animal experiments. S.M., M.dB., A.vdL. and Ö.A. conducted the BARIA cohort. M.B. and M.D. performed bioinformatic analyses. W.M.dV., C.B., H.Y. and C.M. provided bacterial cultures. 


\section{Conflicts of interest}

647 M.N. and W.M.dV. are in the Scientific Advisory Board of Caelus Pharmaceuticals,

648 the Netherlands M.N. is in the SAB of Kaleido, USA and W.M.dV. is in the SAB of A-

649 Mansia, Belgium. However, none of these are directly relevant to the current paper.

650 


\begin{tabular}{|c|c|c|}
\hline REAGENT or RESOURCE & SOURCE & IDENTIFIER \\
\hline \multicolumn{3}{|l|}{ Antibodies } \\
\hline HRP Anti-Human IgG & BD Biosciences & Cat. \#555788 \\
\hline HRP Anti-Human IgM & Abcam & Cat. \#ab205628 \\
\hline HRP Anti-Human IgA & Abcam & Cat. \#ab98558 \\
\hline \multicolumn{3}{|l|}{ Bacterial and Virus Strains } \\
\hline Enterobacter cloacae NCDC 279-56 & DSMZ & DSM 30054 \\
\hline Enterobacter cloacae $\Delta$ flic $\Delta$ fljB & This paper & $\mathrm{N} / \mathrm{A}$ \\
\hline Faecalibacterium prausnitzii A2-165 & Willem de Vos & DSM 17677 \\
\hline Bacteroides ovatus 3_8_47FAA & Willem de Vos & NA \\
\hline Escherichia coli K12, wild type strain & DSMZ & DSM 5911 \\
\hline \multicolumn{3}{|l|}{ Chemicals, Peptides, and Recombinant Proteins } \\
\hline TriPure $^{\mathrm{TM}}$ isolation reagent (Roche) & Sigma & Cat. \#11667165001 \\
\hline Luria broth base & Invitrogen & Cat. \#12780052 \\
\hline Nutrient Broth & ThermoFisher & Cat. \#CM0001B \\
\hline SensiFAST ${ }^{\mathrm{TM}}$ cDNA Synthesis Kit & Bioline & Cat. \#BIO-65054 \\
\hline Flagellin from Salmonella typhimurium & Invivogen & Cat. \#t|rl-stfla \\
\hline LPS from E.coli & & Cat. \#t|r|-eklps \\
\hline Clodroante and control liposome & Liposome research & Cat. \#CP-005-005 \\
\hline TH1020 (TLR5 inhibitor) & Sigma & Cat. \#SML1741 \\
\hline High fat diet $(60 \%$ kcal fat $)$ & Research diets & Cat. \#D12492 \\
\hline Hanks balanced salt-solution & Gibco & Cat. \#70011044 \\
\hline Collagenase XI & Sigma & Cat. \#C7657 \\
\hline \multicolumn{3}{|l|}{ Critical Commercial Assays } \\
\hline QuantiPro $^{\text {TM }}$ BCA Assay Kit & Sigma & Cat. \#QPBCA-1KT \\
\hline ELISA MAXTM Deluxe Set Mouse IL-6 & BioLegend & Cat. \#431304 \\
\hline IL-6 human uncoated ELISA kit & Invitrogen & Cat. \#88-7066-88 \\
\hline QIAamp® Blood Mini Kit & Qiagen & Cat. \#51104 \\
\hline CellTiter-Glo® Luminescent Cell Viability Assay & Promega & Cat. \#G7570 \\
\hline Rat/Mouse Proinsulin ELISA & Mercodia & Cat. \#10-1232-01 \\
\hline Mouse Ultrasensitive Insulin ELISA & ALPCO & $\begin{array}{l}\text { Cat. \#80-INSMSU- } \\
\text { E01 }\end{array}$ \\
\hline \multicolumn{3}{|l|}{ Experimental Models: Cell Lines } \\
\hline HEK-Blue ${ }^{\text {TM }}$ hTLR4 cells & InvivoGen & Cat. \#hkb-htlr4 \\
\hline HEK-Blue $^{\text {TM }}$ hTLR4 cells & InvivoGen & Cat. \#hkb-htlr5 \\
\hline INS-1E cells & AddexBio & Cat. \#C0018009 \\
\hline \multicolumn{3}{|l|}{ Experimental Models: Organisms/Strains } \\
\hline TLR2 KO mice & $\begin{array}{l}\text { The Jackson } \\
\text { Laboratory }\end{array}$ & Stock \#004650 \\
\hline TLR4 KO mice & $\begin{array}{l}\text { The Jackson } \\
\text { Laboratory }\end{array}$ & Stock \#007227 \\
\hline TLR5 KO mice & $\begin{array}{l}\text { The Jackson } \\
\text { Laboratory }\end{array}$ & Stock \#008377 \\
\hline C57BL/6J DIO mice & $\begin{array}{l}\text { The Jackson } \\
\text { Laboratory }\end{array}$ & Stock \#380050 \\
\hline C57BL/6J mice & Charles River & \\
\hline
\end{tabular}




\section{LEAD CONTACT AND MATERIALS AVAILABILITY}

655 Further information and requests for resources and reagents should be directed to and 656 will be fulfilled by the Lead Contact, Daniel $H$. van Raalte 657 (d.vanraalte@amsterdamumc.nl) or Torsten P.M. Scheithauer 658 (t.p.scheithauer@amsterdamumc.nl). For bacterial mutants, please contact Bruce A. 659 Vallance (bvallance@cw.bc.ca)

\section{EXPERIMENTAL MODEL AND SUBJECT DETAILS}

662

663

664

665

666

667

668

669

670

671

672

673

674

675

676

677

678

679

680

681

\section{Participants}

For the current study we included 803 people of Dutch descent with available data on the gut microbiome from the HELIUS cohort in Amsterdam the Netherlands (Snijder et al., 2017). For details, regarding the HELIUS study (recruitment, data collection) in general, and regarding this selection in particular, see Deschasaux et al. (2018). For microbiome analysis, 150 participants were randomly selected and diabetic participants $(n=100)$ were age-BMI-sex matched to healthy non-diabetic controls ( $n=$ 50). Diabetic participants were selected according to one of the following criteria (at least one): self-reported diagnosis of T2D, use of antidiabetic medication, fasting blood glucose $>7.0 \mathrm{mmol} / \mathrm{L}$ and $\mathrm{HbA} 1 \mathrm{c}>48 \mathrm{mmol} / \mathrm{mol}$. All participants did not use antibiotics for the last 3 months.

The HELIUS data are owned by the Amsterdam UMC, location AMC in Amsterdam, The Netherlands. Any researcher can request the data by submitting a proposal to the HELIUS

Executive

Board

as

outlined

at

http://www.heliusstudy.nl/en/researchers/collaboration,

by

email: heliuscoordinator@amsterdamumc.nl. The HELIUS Executive Board will check proposals for compatibility with the general objectives, ethical approvals and informed consent forms of the HELIUS study. There are no other restrictions to obtaining the data and all data requests will be processed in the same manner.

682 To validate our results in the HELIUS cohort, we included 40 T2D participants and 40 683 non-diabetic, age, sex and BMI matched controls of the BARIA cohort. For details, see 
684 Van Olden et al. (2021). The BARIA Study aims to assess how microbiota and their 685 metabolites affect transcription in key tissues and clinical outcome in obese subjects 686 and how baseline anthropometric and metabolic characteristics determine weight loss 687 and glucose homeostasis after bariatric surgery.

688 The studies were approved by the local Institutional Review Board of the Amsterdam 689 UMC, location AMC in Amsterdam, the Netherlands, and conducted in accordance with 690 the Declaration of Helsinki.

692 Bacteria

693 Enterobacter cloacae NCDC 279-56 and Escherichia coli K12 were cultured in Luria 694 broth base (Invitrogen, US) and on LB Agar (Invitrogen, US) at $37^{\circ} \mathrm{C}$, overnight, before 695 being used for experiments. Faecalibacterium prausnitzii A2-165 in YCFA media and 696 Bacteroides ovatus 3_8_47FAA in YZFAA media.

\section{Animals}

699 C57BL/6J mice were purchased from Charles River (France) and maintained under 700 specific pathogen free conditions in the S-building of the Amsterdam UMC, location 701 AMC. TLR2 KO, TLR4 KO, TLR5 KO and C57BL/6J DIO mice were purchased from 702 Jackson Laboratory (JAX); control animals on C57BL/6J background were used from 703 JAX facilities instead of Charles River. All animals were socially housed, under a $12 \mathrm{~h}$ 704 light/dark cycle until 12-14 weeks and sacrificed for pancreatic islets isolation. Only 705 male mice were included in this study. Animal work was performed in accordance with the Central Commission for Animal Experiments (CCD, The Netherlands). 
METHOD DETAILS

708

709

710

711

712

713

714

715

716

717

718

719

720

721

722

723

724

725

726

727

728

729

730

731

732

733

734

735

736

\section{Reagents and Antibodies}

Luria broth base (Invitrogen, US), LB Agar (Invitrogen, US), sterile PBS (Fresenius Kabi, Germany), pentobarbital (EUTANASIA), collagenase XI (Sigma-Aldrich, US), Hanks balanced salt-solution (HBSS w/o calcium and magnesium, Gibco, US), RPMI 1640 (Gibco $^{\text {TM }}$, US), fetal bovine serum (FBS, Capricorn, Germany), PenicillinStreptomycin (P/S, Gibco, US), bovine serum albumin (BSA, RIA grade, Sigma, US), RIPA lysis buffer (ThermoScientific ${ }^{T M}$, US), TriPure ${ }^{T M}$ isolation reagent (Roche, Switzerland), GlycoBlue ${ }^{T M}$ (Invitrogen ${ }^{T M}$, US), UltraPure ${ }^{T M}$ DNase/RNase-Free Distilled Water (Invitrogen ${ }^{\mathrm{TM}}$, US), SensiFAST ${ }^{\mathrm{TM}}$ CDNA Synthesis Kit (Bioline, UK), SensiFAST ${ }^{\mathrm{TM}}$ SYBR® No-ROX Kit (Bioline, UK), DMEM (high glucose, Gibco ${ }^{\mathrm{TM}}$, US), $\beta$-Mercaptoethanol (Sigma, US), sodium pyruvate (Gibco ${ }^{T M}$, US), HRP Anti-Human IgG (BD Biosciences, US), HRP Anti-Human IgM (Abcam, UK), HRP Anti-Human IgA (Abcam, UK), Tween20 (Merck), 1-Step ${ }^{\text {TM }}$ Ultra TMB-ELISA Substrate Solution (ThermoScientific ${ }^{T M}$, US), mouse ultrasensitive insulin ELISA (ALPCO, US), QuantiPro $^{\mathrm{TM}}$ BCA Assay Kit (Sigma, US), ELISA MAX ${ }^{\mathrm{TM}}$ Deluxe Set Mouse IL-6 (BioLegend, US), IL-6 human uncoated ELISA kit (Invitrogen ${ }^{\mathrm{TM}}$, US), clodronate and control liposome (Liposome research, The Netherlands), TH1020 (Sigma, US), CellTiter-Glo® Luminescent Cell Viability Assay (Promega, US), Rat/Mouse Proinsulin ELISA (Mercodia, SE).

\section{Heat-inactivation of bacteria}

The optical density of the bacterial culture was measured at $600 \mathrm{~nm}$ (OD600) and diluted to 1 E9 colony forming units (CFUs) per $\mathrm{mL}$. Bacteria were centrifuged at 8000 $\mathrm{xg}$ for 5 minutes and resuspended in $1 \mathrm{~mL}$ sterile phosphate buffered saline (PBS). All bacteria were heat-inactivated at $70^{\circ} \mathrm{C}$ for $30 \mathrm{~min}$ and stored at $-80^{\circ} \mathrm{C}$ in small aliquots for further use.

\section{Pancreatic surgery}


737 Individuals who are scheduled for pancreatic surgery (e.g., pylorus-preserving 738 pancreatoduodenectomy or Whipple's procedure), because of pancreatic carcinoma, were asked to donate healthy tissue surrounding the tumor. Tissue was harvested under surgical conditions, snap frozen in liquid nitrogen and stored at $-80^{\circ} \mathrm{C}$ until further analysis.

\section{Pancreatic islet isolation}

Mice were anaesthetized with $2.5 \mathrm{mg}$ pentobarbital (diluted in sterile saline) per mouse and sacrificed via cervical dislocation. After clamping the Ampulla of Vatar, the pancreas was injected intraductally with approximately $3 \mathrm{~mL}$ of collagenase $\mathrm{XI}$ (1000 $\mathrm{U} / \mathrm{ml}$ ) in HBSS (without calcium chloride) and placed in $50 \mathrm{~mL}$ tubes with an additional $2 \mathrm{~mL}$ of collagenase solution. The pancreas was incubated at $37^{\circ} \mathrm{C}$ for 13 minutes followed by gentle shaking to obtain a homogenously dispersed pancreas. Digestion was stopped with cold HBSS supplemented with $1 \mathrm{mM} \mathrm{CaCl}$. Islets were washed two times in cold HBSS with $\mathrm{CaCl}_{2}$ by centrifuging $185 \mathrm{xg}$ for 30 seconds. Next, islets were filtered through a $70 \mu \mathrm{M}$ prewetted cell strainer. After flushing two times with $10 \mathrm{~mL}$ of HBSS with $\mathrm{CaCl}_{2}$, the strainer was turned upside-down over a Petri dish and rinsed with $16 \mathrm{~mL}$ of islet media (RPMI 1640 with GlutaMAXTM $1 \mathrm{x}, 10 \%$ FBS and P/S $1 \mathrm{x}$ ) to collect the islets into the dish. Islets were handpicked under the Nikon SMZ800 microscope into a fresh Petri dish with islet media. Islets were rested overnight to recover from isolation procedure.

\section{Plasmid construction.}

760 Overlap extension PCR (Ho et al., 1989) was used to generate pRE118-pheS- $\Delta$ fliC 761 and pRE118-pheS- $\triangle$ fljB constructs (pRE118-pheS was a gift from Christopher Hayes 762 of UC Santa Barbara). For pRE118-pheS- $\triangle$ fliC construct, two PCR fragments were amplified using E. cloacae genomic DNA as the template. Primer pairs used to amplify 
GACAGTGAGCTCGCATCGTTAACGCGTCTTCACCAA-3'), respectively. This results in a 789-bp fragment containing the upstream of fliC and a 750-bp fragment containing the downstream of the fliC, respectively. These two PCR fragments were then mixed and used as the template for a secondary PCR (with primer pairs ecFliC-P1 containing a Kpnl restriction enzyme site and ecFliC-P4 containing a Sacl restriction enzyme site). The 16-bp overlapping sequence (underlined) in primers ecFliC-P2 and ecFliC-P3 allows the amplification of a 1,539-bp PCR product. This PCR product was digested with Kpnl and Sacl, and directly cloned into the E. cloacae suicide vector pRE118pheS (Kanr).

The pRE118-pheS- $\Delta$ fliC construct was generated the same as above. Primer pairs used to amplify the PCR fragments are FljB-P1 (5'GCACGTCTAGAGTGACCTTTATCGTCATCTCACCGT-3') plus FljB-P2 (5'GTACCCAGCTGAGTCTGGGATTTGTTCAGGTTGTT-3'), and FljB-P3 (5'AGACTCAGCTGGGTACTGCTGCGTTAATCTGCGTTA-3') plus FljB-P4 (5'GACAGTGAGCTCGTACAGCTATTCGCTGCATAACGA-3'), respectively. This results in a 955-bp fragment containing the upstream of $f l j B$ and a 950-bp fragment containing the downstream of the $f l j B$, respectively. These two PCR fragments were then mixed and used as the template for a secondary PCR (with primer pairs FljB-P1 containing a Xbal restriction enzyme site and FljB-P4 containing a Sacl restriction enzyme site). The 16-bp overlapping sequence (underlined) in primers FljB-P2 and FljB-P3 allows the amplification of a 1,905-bp PCR product. This PCR product was digested with Xbal and Sacl, and directly cloned into the E. cloacae suicide vector pRE118-pheS.

\section{Generation of E. cloacae mutant strains}

pRE118-pheS- $\triangle$ fliC and pRE118-pheS- $\Delta$ fljB constructs were transformed into $E$. coli $\operatorname{MFD}(\lambda$ pir $)$. E. coli MFD $(\lambda$ pir $)$ carrying these constructs and WT E. cloacae were grown overnight in LB, and then mixed at a ratio of $4: 1$ (donor vs recipient strains). To make $\square$ fljB $\square$ fliC, E. coli MFD( $\lambda$ pir) carrying pRE118-pheS- $\Delta$ fljB and $\Delta$ fliC were grown overnight in LB, and then mixed at a ratio of $4: 1$. Fifty microliter of the mixture was spotted onto LB agar plate containing diaminopimelic acid (DAP, $0.3 \mathrm{mM}$ ), and incubated at $37^{\circ} \mathrm{C}$ overnight. This was followed by scaping the cell mixtures in PBS 
799

800

801

802

803

804

805

806

807

808

809

810

811

812

813

814

815

816

817

818

819

820

821

822

823

824

825

826

827

and plating onto LB agar containing streptomycin $(100 \mu \mathrm{g} / \mathrm{ml})$ and kanamycin (50 $\mu \mathrm{g} / \mathrm{ml}$ ). The resulting single-crossover mutants were grown statically in LB at $37^{\circ} \mathrm{C}$ overnight, and further counter selected on M9 minimal medium agar plates containing $0.4 \%(w / v)$ glucose and 0.1\% (w/v) p-chlor-ophenylalanine (Ting et al., 2020). Kanamycin sensitive colonies were screened by colony PCR. The $\triangle$ fliC deletion mutant was confirmed by PCR with primers ecFliC-check-F (5'GCGTTTCTGATGGCGTTCTGAA-3') and ecFliC-check-R GCTCGAACTTGTTCATCCCGATT-3'). The predicted size of WT and mutant bands is 1201-bp and 362-bp, respectively. The $\triangle$ fljB deletion mutant was confirmed by PCR with primers FljB-check-F (5'-GCAGAACAACCTGAACAAATCCCA-3') and FljBcheck-R (5'-GACACGTTTACGCCGGTTCACTAT-3'). The predicted size of WT and mutant bands is 1811-bp and 387-bp, respectively.

\section{Confirming mutants with a swimming motility assay.}

WT and mutant E. cloacae strains $(\triangle f l j B, \Delta f l i C, \Delta f l j B \Delta f l i C)$ were grown statically in $2 \mu \mathrm{l}$ of LB at $30{ }^{\circ} \mathrm{C}$ for $18 \mathrm{~h}$. Two microliter of these cultures were spotted onto semi-solid nutrient broth (BD) agar plates containing $0.3 \%$ agar. After incubating the plates at 37 ${ }^{\circ} \mathrm{C}$ for $4 \mathrm{~h}$, pictures showing the swimming motility were taken (Figure S8). (1)

\section{Glucose stimulated insulin secretion}

Pancreatic islets or $\beta$-cell lines (see seeding below) were washed in a 12 well plate $2 x$ with 500 uL low glucose Krebs-Ringer buffer (KRB; $132 \mathrm{mM} \mathrm{NaCl,} 5 \mathrm{mM} \mathrm{KCl,} 1 \mathrm{mM}$ $\mathrm{KH}_{2} \mathrm{PO}_{4}, 1 \mathrm{mM} \mathrm{MgSO}_{4}, 2.5 \mathrm{mM} \mathrm{CaCl}_{2}, 5 \mathrm{mM} \mathrm{NaHCO}_{3}, 10 \mathrm{mM}$ HEPES, 0.25\% BSA, $1.64 \mathrm{mM}$ glucose) and starved in $500 \mathrm{uL}$ low glucose KRB for 1 hour. Islets were split into 10 islets per well in a 12 well plate (triplicates) and incubated for 1 hours in $500 \mathrm{uL}$ low glucose KRB. The same islets were transferred into $500 \mathrm{uL}$ high glucose KRB (16.4 $\mathrm{mM}$ ) for 1 hour. Finally, islets were washed 2x with $1 \mathrm{~mL}$ PBS and lysed with $150 \mathrm{uL}$ RIPA buffer. Islet lysate was spun at $14.000 \times \mathrm{xg}$ for $10 \mathrm{~min}$ at $4^{\circ} \mathrm{C}$ and the supernatant was stored at $-20^{\circ} \mathrm{C}$ until further use. 
829

830

831

832

833

834

835

836

837

838

839

840

841

842

843

844

845

846

847

848

849

850

851

852

853

854

855

856 Fecal bacteria were measured via quantitative PCR with the aid of PCR machine 857 (BioRad, US). SensiFAST ${ }^{T M}$ SYBR ${ }^{\circledR}$ No-ROX Kit was used according to manufactures

858 instructions. For each well, $10 \mathrm{ng}$ genomic DNA and $300 \mathrm{nM}$ primer mix were used in

\section{DNA isolation}

Fecal DNA was extracted from $150 \mathrm{mg}$ fecal material and the sorted fractions using a repeated bead beating protocol (method 5) (Costea et al., 2017). DNA was purified using Maxwell RSC Whole Blood DNA Kit. 16S rRNA gene amplicons were generated as described below.

\section{RNA isolation and cDNA synthesis}

RNA was isolated with TriPure ${ }^{T M}$ isolation reagent (Roche). Cells were separated from the culture media and $300 \mathrm{uL}$ TriPure $^{\mathrm{TM}}$ was added. After lysis, $60 \mathrm{uL}$ chloroform was added, the mixture was vigorously shaken for 15 seconds and incubated for 3 minutes at room temperature. Next, samples were spun for 15 minutes at $12.000 \mathrm{xg}\left(4^{\circ} \mathrm{C}\right)$ and the aqueous phase was mixed with $190 \mathrm{uL}$ isopropanol with $0.44 \mathrm{uL} \mathrm{GlycoBlue}{ }^{\mathrm{TM}}$. After an overnight incubation at $-20^{\circ} \mathrm{C}$, samples were spun at $12.000 \mathrm{xg}$ for 10 minutes $\left(4^{\circ} \mathrm{C}\right)$ and the pellet was $2 \mathrm{x}$ washed with $1 \mathrm{~mL}$ of $75 \%$ ethanol $\left(7.500 \mathrm{xg}, 5\right.$ minutes, $\left.4^{\circ} \mathrm{C}\right)$. Next, the pellet was dried at room temperature for 10 minutes, $18 \mathrm{uL}$ RNase free $\mathrm{H} 2 \mathrm{O}$ was added and incubated at $56^{\circ} \mathrm{C}$ for 10 minutes. RNA concentration was measured with Nanodrop. cDNA synthesizes was performed with SensiFAST ${ }^{\mathrm{TM}}$ CDNA Synthesis Kit according to manufactures instructions.

\section{PCRs}

Gene expression was measured via real time quantitative PCR (RT-qPCR) with the aid of PCR machine (BioRad, US). SensiFAST ${ }^{T M}$ SYBR ${ }^{\circledR}$ No-ROX Kit was used according to manufactures instructions. For each well, $7.5 \mathrm{ng} \mathrm{cDNA}$ and $1 \mu \mathrm{M}$ primer mix were used in a $10 \mathrm{uL} \mathrm{PCR} \mathrm{mix.} \mathrm{For} \mathrm{primers} \mathrm{see} \mathrm{Table} \mathrm{S6.} \mathrm{Temperatures} \mathrm{are} \mathrm{used}$ as following, if not stated differently: $95^{\circ} \mathrm{C}$ for 10 minutes, 40 cycles of $95^{\circ} \mathrm{C}$ for 15 seconds and $60^{\circ} \mathrm{C}$ for 30 seconds with a plate reading, followed by a melt curve with increment of $0.5^{\circ} \mathrm{C}$ every 5 seconds starting from $65^{\circ} \mathrm{C}$ to $95^{\circ} \mathrm{C}$. 
859 a 10 uL PCR mix. For primers see Table S6. For total bacterial in feces, EUBAC 860 primers and temperature settings were used as stated (Nadkarni et al., 2002). For 861 Enterobacteriaceae detection, En-lsu3 was used as described (Matsuda et al., 2007). 862 Primers for Enterobacter cloacae was designed for the V3V4 regions. Temperatures 863 as described above were used. Standard amplicons were made with genomic DNA 864 from E.coli or E. cloacae and Taq DNA Polymerase (Qiagen, Germany) according to 865 manufactures instructions. Amplicons were cleaned with QIAquick PCR purification Kit 866 (Qiagen, Germany). Copy numbers were calculated according to the standard curve.

\section{Cell lines}

869 HEK-Blue ${ }^{\text {TM }}$ hTLR5 cells were used according to manufactures instructions. For 870 flagellin detection in the blood circulation, $20 \mathrm{uL}$ serum was used per well (96 well 871 plate) and mixed with $180 \mathrm{uL}$ of $1.4 \times 1 \mathrm{E} 5 \mathrm{cells} / \mathrm{mL}$ in detection media. Cells were 872 incubated for 16 hours and the supernatant was read at OD620. INS-1E cells were 873 cultured in RPMI 1640 media (5\% FBS, 1x P/S, 1x HEPES, $50 \mu$ M $\beta$-mercaptoethenol, $8741 \mathrm{x}$ sodium pyruvate) and passaged with $0.25 \%$ Trypsin-EDTA. Cells were seeded in a 87512 well plate at 75.000 cells $/ \mathrm{mL}$, rested overnight and incubated with heat-inactivated 876 bacteria for 72 hours.

\section{Antibody analysis}

879 Bacteria were grown overnight and the optical density was measured at OD600. 880 Bacteria were diluted to have 1 E9 CFUs $/ \mathrm{mL}$ and washed with $1 \mathrm{~mL}$ sterile PBS (8000 $881 \mathrm{xg}, 5$ minutes, $4^{\circ} \mathrm{C}$ ). Bacteria were sonicated on ice at $30 \%$ amplitude for $20 \times 30$ 882 seconds cycles with 60 seconds intervals. Nunc ${ }^{\text {TM }}$ MicroWell ${ }^{\text {TM }} 96$-well microtiterplates 883 (ThermoScientific ${ }^{\text {TM }}$, US) were coated with 200.000 sonicated bacteria per well (100 $884 \mathrm{uL}$ ) overnight at $4^{\circ} \mathrm{C}$. Plates were washed $3 x$ with $300 \mathrm{uL}$ per well of PBS and blocked 885 with 150 uL PBS with 1\% BSA for 2 hours at room temperature. Plates were washed 886 again with PBS, 100 uL of 250x diluted serum samples (PBS/BSA) was added and 887 incubated for 4 hours at room temperature. Plates were washed $3 x$ with PBS with $8880.05 \%$ Tween20 and $100 \mathrm{uL}$ of secondary antibody (2000x diluted HRP anti-Human 889 IgG; 50.000x diluted HRP anti-human IgM; 20.000x diluted HRP anti-human $\lg A$; in 
890 PBS/Tween20) was added for 2 hours at room temperature. Plates were washed with 891 PBS again and $100 \mathrm{uL}$ of TMB was added for 15 minutes. The reaction was stopped with $50 \mathrm{uL}$ of $0.5 \mathrm{M} \mathrm{HCl}$ and read at OD450.

893 Pancreatic biopsies were 10x diluted according to tissue weight and homogenized in 894 ultrapure water (Invitrogen, US) with the aid of a sterile metal bead. The homogenate 895 was spun Nunc $^{\mathrm{TM}}$ MicroWell ${ }^{\mathrm{TM}}$ 96-well microtiterplates (ThermoScientific ${ }^{\mathrm{TM}}$, US) were 896 coated overnight $\left(4^{\circ} \mathrm{C}\right)$ with $100 \mathrm{ng}$ per well of flagellin from Salmonella typhimurium 897 (Invivogen, US). The plates was washed 3x with 300 uL PBS/Tween20. Afterwards, $898100 \mathrm{uL}$ of homogenized pancreas was added and incubated for $1 \mathrm{~h}$ at $37^{\circ} \mathrm{C}$. The plates 899 was washed $3 x$ with 300 uL PBS/Tween20. Secondary antibodies and TMB were 900 added as described above.

901

902

\section{ELISA}

903 Insulin was measured in low glucose KRB, high glucose KRB and cell lysate from GSIS 904 experiments with ALPCO mouse ultrasensitive insulin ELISA according to 905 manufactures instructions. Concentrations were normalized to total protein content 906 measured via QuantiPro ${ }^{T M}$ BCA Assay Kit. Proinsulin ELISA (Mercodia) was 907 performed according to manufactures instructions. IL-6 concentrations were measured 908 in cell supernatants via ELISA MAX ${ }^{\text {TM }}$ Deluxe Set Mouse IL-6 and IL-6 human uncoated ELISA kit according to manufactures instructions.

Monocyte isolation

912 PBMCs were isolated with Lymphoprep (GE Healthcare) and CD14 MACS beads (Miltenyi) according to manufactures instructions.

\section{Macrophage depletion}

916 Pancreatic islet macrophages were depleted with Clodronate-liposome. Islets were 917 isolated and rested for 3 hours. Islets were picked in a small petri dish (40-70 islets per 918 dish) and treated with either clodronate or control liposome for $48 \mathrm{~h}$ (1 in 5 diluted in 
919 islet media). Islets were washed $3 x$ with $2 \mathrm{~mL}$ complete media and picked in fresh 920 media.

\section{Library preparation and sequencing}

923 Library preparation and sequencing was performed at the Wallenberg Laboratory 924 (Sahlgrenska University of Gothenburg, Sweden). Fecal microbiome composition was profiled by sequencing the V4 region of the 16S rRNA gene on an Illumina MiSeq instrument (Illumina RTA v1.17.28; MCS v2.5) with 515F and 806R primers designed for dual indexing (Kozich et al., 2013) and the V2 Illumina kit (2x250 bp paired-end reads). 16S rRNA genes from each sample were amplified in duplicate reactions in volumes of $25 \mu \mathrm{L}$ containing 1x Five Prime Hot Master Mix (5 PRIME GmbH), $200 \mathrm{nM}$

930 of each primer, $0.4 \mathrm{mg} / \mathrm{ml} \mathrm{BSA}, 5 \%$ DMSO and $20 \mathrm{ng}$ of genomic DNA. PCR was

931 carried out under the following conditions: initial denaturation for $47 \mathrm{~min}$ at $94^{\circ} \mathrm{C}$, followed by 25 cycles of denaturation for $45 \mathrm{sec}$ at $94^{\circ} \mathrm{C}$, annealing for $60 \mathrm{sec}$ at $52^{\circ} \mathrm{C}$ and elongation for $90 \mathrm{sec}$ at $72^{\circ} \mathrm{C}$, and a final elongation step for 10 min at $72^{\circ} \mathrm{C}$.

934 Duplicates were combined, purified with the NucleoSpin Gel and PCR Clean-up kit (Macherey-Nagel) and quantified using the Quant-iT PicoGreen dsDNA kit (Invitrogen).

936 Purified PCR products were diluted to $10 \mathrm{ng} / \mu \mathrm{L}$ and pooled in equal amounts. The 937 pooled amplicons were purified again using Ampure magnetic purification beads 938 (Agencourt) to remove short amplification products; for negative controls, see 939 Deschasaux et al. (2018). Libraries for sequencing were prepared by mixing the pooled 940 amplicons with PhiX control DNA purchased from Illumina. The input DNA had a 941 concentration of 3 pM and contained 15\% PhiX and resulted in the generation of about $942700 \mathrm{~K}$ clusters/mm2 and an overall percentage of bases with quality score higher than 94330 (Q30) higher than 70\%.

\section{Bioinformatic pipeline}

946 USEARCH (v11.0.667_i86linux64) was used to process the raw sequencing reads. 947 For paired-end merging, we used 30 max. allowed differences in the overlapping 948 region ("maxdiffs") for the merging step (using the "fastq_mergepairs" command) and 949 max. 1 expected errors ("fastq_maxee") as a quality filter threshold (using the 
950 "fastq_filter" command). Expected error-based read quality filtering is described in 951 detail in Edgar et al. 2015. After merging paired-end reads and quality filtering, remaining contigs were dereplicated and unique sequenced were denoised using the UNOISE3 algorithm in order to obtain Amplicon Sequence Variants (ASVs). All merged reads were subsequently mapped against the resulting ASVs to produce an ASV table. ASVs not matching expected amplicon length were filtered out (i.e. ASV sequences longer than $260 \mathrm{bp}$ or shorter than $250 \mathrm{bp}$ ). Taxonomy was assigned with the 'assignTaxonomy' function from the 'dada2' R package ( $v$ 1.12.1) and the SILVA ( $v$. 132) reference database. ASVs sequences were then aligned using MAFFT (v.7.427) using the auto settings. A phylogentic tree was constructed from the resulting multiple sequence alignment with FastTree (v.2.1.11 Double Precision) using a generalized time-reversible model ('-gtr'). The AVS table, taxonomy and tree were integrated using the 'phyloseq' R package (v.1.28.0). The ASV table was rarefied to 14932 counts per sample with vegan v2.5-6. Of 6056 sequenced samples, 24 had insufficient counts ( $<5000$ counts per sample) and were excluded at the rarefaction stage. The final dataset thus contained 6032 samples and 22532 ASVs. Functional composition was inferred using PICRUSt2 (2.2.0b).

\section{Cell viability}

969 Cell viability of was measured with CellTiter-Glo® Luminescent Cell Viability Assay 970 (Promega) according to manufactures instructions. 10 size matched islets were used 971 per replicate with 5 replicates per experiment. Luminescence was read with Promega 972 GLOMAX ${ }^{\mathrm{TM}}$ multi detection system.

\section{Statistical analysis}

975 Data were checked for normality with the Shapiro-Wilk test. Paired or unpaired t-test 976 was performed for normal continuous variables and the Wilcoxon signed rank test or 977 Mann-Whitney for other variables. Spearman correlation was used for all correlation 978 analysis. 2-way ANOVA with Šidák multiple comparison was used for glucose and 979 insulin tolerance tests. Statistical analyses were performed using Prism, version 8.3.0 980 (GraphPad Software, US). Data are provided as mean with SEM . P-values $<0.05$ 
bioRxiv preprint doi: https://doi.org/10.1101/2021.10.07.463317; this version posted October 7, 2021. The copyright holder for this preprint (which was not certified by peer review) is the author/funder. All rights reserved. No reuse allowed without permission.

981 were considered statistically significant. All authors had access to the study data and 982 reviewed and approved the final manuscript. 


\section{Supplementary information}

984

Table S1: Patient characteristics of the Dutch participants of the HELIUS cohort 986 (complementary to Figure 1A).

987 Dutch origin people of the HELIUS cohort are shown. Data shown are mean \pm SD for 988 patient characteristics. Mann-Whitney test was used for statistical significance. 989 Abbreviations: ND, no diabetes; T2D, Type 2 diabetes; HbA1c, glycated hemoglobin.

\begin{tabular}{|l|c|c|c|}
\hline & ND & T2D & p value \\
\hline $\mathrm{n}$ & 712 & 91 & n.d. \\
\hline Sex $(\%$ female) & 57 & 34 & $<0.0001$ \\
\hline Age (years) & $45.8 \pm 13.0$ & $61.7 \pm 5.9$ & $<0.0001$ \\
\hline Body mass index $\left(\mathrm{kg} / \mathrm{m}^{2}\right)$ & $23.8 \pm 3.5$ & $29.2 \pm 4.7$ & $<0.0001$ \\
\hline HbA1c $(\mathrm{mmol} / \mathrm{mol})$ & $34.3 \pm 2.7$ & $46.9 \pm 8.2$ & $<0.0001$ \\
\hline
\end{tabular}

991 Table S2: Gut microbiota composition of HELIUS cohort (complementary to 992 Figure 1A).

993 Only a subset of Dutch origin people of the HELIUS cohort are shown. The 16S rRNA 994 of the fecal microbiota was sequenced via miSeq (family level). Data shown are 995 median. Abbreviations: ND, no diabetes; T2D, Type 2 diabetes.

\begin{tabular}{|r|c|c|}
\hline Bacterial family & ND ( $\mathbf{~ = 7 1 2 )}$ & T2D ( $\mathbf{~ = ~ 9 1 ) ~}$ \\
\hline Bacteroidales_Rikenellaceae & 1.62 & 1.22 \\
\hline Bacteroidales_Barnesiellaceae & 0.44 & 0.31 \\
\hline Bacteroidales_Muribaculaceae & 0.54 & 0.67 \\
\hline Bacteroidales_Prevotellaceae & 9.25 & 10.30 \\
\hline Bacteroidales_Bacteroidaceae & 7.90 & 8.20 \\
\hline Bacteroidales_Tannerellaceae & 0.71 & 0.78 \\
\hline Clostridiales_Lachnospiraceae & 30.10 & 31.69 \\
\hline Clostridiales_Peptostreptococcaceae & 1.08 & 0.71 \\
\hline Verrucomicrobiales_Akkermansiaceae & 0.83 & 0.55 \\
\hline Desulfovibrionales_Desulfovibrionaceae & 0.39 & 0.60 \\
\hline Betaproteobacteriales_Burkholderiaceae & 0.68 & 0.74 \\
\hline Enterobacteriales_Enterobacteriaceae & 0.35 & 1.08 \\
\hline Bifidobacteriales_Bifidobacteriaceae & 2.34 & 1.57 \\
\hline Coriobacteriales_Eggerthellaceae & 0.62 & 0.62 \\
\hline
\end{tabular}




\begin{tabular}{|r|c|c|} 
Coriobacteriales_Coriobacteriaceae & 1.24 & 1.55 \\
\hline Selenomonadales_Veillonellaceae & 1.74 & 1.92 \\
\hline Selenomonadales_Acidaminococcaceae & 0.88 & 1.16 \\
\hline Erysipelotrichales_Erysipelotrichaceae & 2.06 & 2.66 \\
\hline Lactobacillales_Streptococcaceae & 0.52 & 0.96 \\
\hline Clostridiales_Christensenellaceae & 1.95 & 1.68 \\
\hline Clostridiales_Clostridiaceae_1 & 0.68 & 0.44 \\
\hline Clostridiales_Ruminococcaceae & 30.35 & 27.28 \\
\hline Other & 1.97 & 2.11 \\
\hline & & \\
\hline
\end{tabular}

998 Participants were randomly selected from the HELIUS cohort. People with Type 2 999 diabetes (T2D) were matched to controls without T2D according to age, sex and body 1000 mass index (BMI). Data shown are mean \pm SD. Unpaired t-test was used for age and 1001 BMI. Mann Whitney test for fasting glucose and HbA1c. Abbreviations: n.d., not 1002 determined; BMI, body mass index; HbA1c, glycated hemoglobin.

\begin{tabular}{|r|c|c|c|}
\hline & ND $(\mathbf{n}=\mathbf{5 0})$ & T2D $(\mathbf{n}=\mathbf{1 0 0})$ & p-value \\
\hline Age (years) & $57.2 \pm 6.8$ & $56.8 \pm 6.7$ & 0.7440 \\
\hline Female (\%) & 62 & 62 & 1.0000 \\
\hline BMI $\left(\mathrm{kg} / \mathrm{m}^{2}\right)$ & $29.7 \pm 4.4$ & $29.8 \pm 5.0$ & 0.9673 \\
\hline Fasting glucose $(\mathrm{mmol} / \mathrm{L})$ & $5.35 \pm 0.56$ & $7.13 \pm 1.85$ & $<0.0001$ \\
\hline $\mathrm{HbA1c}(\mathrm{mmols} / \mathrm{mol})$ & $40.0 \pm 4.2$ & $54.5 \pm 15.2$ & $<0.0001$ \\
\hline
\end{tabular}

1003

Table S4. Characteristics of selected participants from BARIA cohort.

Participants were randomly selected from BARIA cohort. People with Type 2 diabetes (T2D) were matched to controls without T2D according to age, sex and body mass index (BMI). Baseline samples were used before bariatric surgery. Data shown are mean \pm SD. Unpaired t-test was used. Abbreviations: n.d., not determined; BMI, body

1009 mass index; HbA1c, Glycated hemoglobin; OD, optical density.

\begin{tabular}{|r|c|c|c|}
\hline & ND $(\mathbf{n}=\mathbf{4 0})$ & T2D $(\mathbf{n}=\mathbf{4 0})$ & p-value \\
\hline Age (years) & $49.2 \pm 9.9$ & $49.4 \pm 10.2$ & 0.9468 \\
\hline Female $(\%)$ & 65 & 65 & 1.000 \\
\hline $\mathrm{BMI}\left(\mathrm{kg} / \mathrm{m}^{2}\right)$ & $39.4 \pm 3.4$ & $39.2 \pm 4.7$ & 0.8666 \\
\hline Fasting glucose $(\mathrm{mmol} / \mathrm{L})$ & $5.7 \pm 0.8$ & $7.3 \pm 1.6$ & $<0.0001$ \\
\hline
\end{tabular}




\begin{tabular}{|r|c|c|c|} 
HbA1c $(\%)$ & $5.7 \pm 0.4$ & $7.3 \pm 1.1$ & $<0.0001$ \\
\hline C-peptide $(\mathrm{nmol} / \mathrm{L})$ & $0.92 \pm 0.3$ & $0.94 \pm 0.4$ & 0.7463 \\
\hline Insulin $(\mathrm{pmol} / \mathrm{L})$ & $91.3 \pm 46.0$ & $189.1 \pm 239.5$ & 0.0144 \\
\hline
\end{tabular}

Table S5. Patient characteristics of diabetic individuals for human pancreatic biopsy

\begin{tabular}{|r|c|}
\hline & T2D $(\mathbf{n}=\mathbf{5})$ \\
\hline Age (years) & $49.4 \pm 10.2$ \\
\hline Sex (M/F) & $3 / 2$ \\
\hline $\mathrm{BMI}\left(\mathrm{kg} / \mathrm{m}^{2}\right)$ & $27.1 \pm 3.0$ \\
\hline $\mathrm{HbA1c}(\%)$ & $7.8 \pm 1.4$ \\
\hline $\begin{array}{r}\text { Diabetes duration } \\
\text { (years) }\end{array}$ & $9 \pm 5$ \\
\hline
\end{tabular}

1014 Table S6. Primer sequences used in this manuscript (both in 5'3'direction).

\begin{tabular}{|c|c|c|c|c|}
\hline Name & Species & Forward & Reverse & Ref. \\
\hline $\begin{array}{l}\text { Eclo_V } \\
3 \mathrm{~V} 4\end{array}$ & $\begin{array}{l}\text { Enterobacter } \\
\text { cloacae }\end{array}$ & $\begin{array}{l}\text { CAGCAATTGACGTTACCC } \\
\text { GC }\end{array}$ & $\begin{array}{l}\text { CAGCCTGCCAGTTTCGAAT } \\
\text { G }\end{array}$ & $\begin{array}{l}\text { This } \\
\text { study }\end{array}$ \\
\hline En-Isu3 & $\begin{array}{l}\text { Enterobacteri } \\
\text { aceae }\end{array}$ & $\begin{array}{l}\text { TGCCGTAACTTCGGGAGA } \\
\text { AGG }\end{array}$ & $\begin{array}{l}\text { TCAAGGCTCAATGTTCAGT } \\
\text { GTC }\end{array}$ & $\begin{array}{l}\text { PMID } \\
17071 \\
791\end{array}$ \\
\hline EUBAC & Bacteria & $\begin{array}{l}\text { TCCTACGGGAGGCAGCAG } \\
\mathrm{T}\end{array}$ & $\begin{array}{l}\text { GGACTACCAGGGTATCTAA } \\
\text { TCCTGTT }\end{array}$ & $\begin{array}{l}\text { PMID } \\
11782 \\
518\end{array}$ \\
\hline RPLP0 & Human & $\begin{array}{l}\text { ACGGGTACAAACGAGTCC } \\
\text { TG }\end{array}$ & $\begin{array}{l}\text { GCCTTGACCTTTTCAGCAA } \\
\text { G }\end{array}$ & $\begin{array}{l}\text { This } \\
\text { study }\end{array}$ \\
\hline RPLP0 & Rat & $\begin{array}{l}\text { GAACATCTCCCCCTTCTC } \\
\text { CTTC }\end{array}$ & $\begin{array}{l}\text { ATTGCGGACACCCTCTAGG } \\
\text { AA }\end{array}$ & $\begin{array}{l}\text { This } \\
\text { study }\end{array}$ \\
\hline Rps18 & Mouse & $\begin{array}{l}\text { CAC TTT TGG GGC CTT } \\
\text { CGT G }\end{array}$ & $\begin{array}{l}\text { GCA AAG GCC CAG AGA } \\
\text { CTC ATT }\end{array}$ & $\begin{array}{l}\text { This } \\
\text { study }\end{array}$ \\
\hline NLRP3 & Mouse & $\begin{array}{l}\text { AGA GCC TAC AGT TGG } \\
\text { GTG AA }\end{array}$ & $\begin{array}{l}\text { CTT CCA ACG CCT ACC } \\
\text { AGG AAA T }\end{array}$ & $\begin{array}{l}\text { This } \\
\text { study }\end{array}$ \\
\hline
\end{tabular}




\begin{tabular}{|c|c|c|c|c|}
\hline NLRP3 & Human & $\begin{array}{l}\text { CAGAACCTGGGGTTGTCT } \\
\text { GAA }\end{array}$ & $\begin{array}{l}\text { GAAGGCTCAAAGACGACG } \\
\text { GT }\end{array}$ & $\begin{array}{l}\text { This } \\
\text { study }\end{array}$ \\
\hline MafA & Human & $\begin{array}{l}\text { GAGAGCGAGAAGTGCCAA } \\
\text { CT }\end{array}$ & $\begin{array}{l}\text { CTTGTACAGGTCCCGCTCT } \\
\text { TT }\end{array}$ & $\begin{array}{l}\text { This } \\
\text { study }\end{array}$ \\
\hline MafA & Mouse & $\begin{array}{l}\text { CAA GGA GGA GGT CAT } \\
\text { CCG AC }\end{array}$ & $\begin{array}{l}\text { TCT CCA GAA TGT GCC } \\
\text { GCT G }\end{array}$ & $\begin{array}{l}\text { This } \\
\text { study }\end{array}$ \\
\hline MafA & Rat & $\begin{array}{l}\text { GCACCCGACTTCTTTCTGT } \\
\text { GA }\end{array}$ & $\begin{array}{l}\text { GCCTCAGAGTCCGAACCG } \\
\text { A }\end{array}$ & $\begin{array}{l}\text { This } \\
\text { study }\end{array}$ \\
\hline PDX1 & Human & $\begin{array}{l}\text { AAA GCT CAC GCG TGG } \\
\text { AAA G }\end{array}$ & $\begin{array}{l}\text { GGC CGT GAG ATG TAC } \\
\text { TTG TTG }\end{array}$ & $\begin{array}{l}\text { This } \\
\text { study }\end{array}$ \\
\hline PDX1 & Mouse & $\begin{array}{l}\text { CAG TGG GCA GGA GGT } \\
\text { GCT TA }\end{array}$ & $\begin{array}{l}\text { GGG CCG GGA GAT GTA } \\
\text { TTT GTT }\end{array}$ & $\begin{array}{l}\text { This } \\
\text { study }\end{array}$ \\
\hline PDX1 & Rat & $\begin{array}{l}\text { TTCATCTCCCTTTCCCGTG } \\
\text { G }\end{array}$ & $\begin{array}{l}\text { GTGTAGGCTGTACGGGTC } \\
\text { CT }\end{array}$ & $\begin{array}{l}\text { This } \\
\text { study }\end{array}$ \\
\hline INS1 & Mouse & $\begin{array}{l}\text { GAC CAT CAG CAA GCA } \\
\text { GGT CAT T }\end{array}$ & $\begin{array}{l}\text { GAC AAA AGC CTG GGT } \\
\text { GGG TT }\end{array}$ & $\begin{array}{l}\text { This } \\
\text { study }\end{array}$ \\
\hline INS1 & Rat & $\begin{array}{l}\text { CACACCCAAGTCCCGTCG } \\
\mathrm{T}\end{array}$ & $\begin{array}{l}\text { AACCTCCAGTGCCAAGGTC } \\
\text { TG }\end{array}$ & $\begin{array}{l}\text { This } \\
\text { study }\end{array}$ \\
\hline INS & Human & $\begin{array}{l}\text { TCT ACC TAG TGT GCG } \\
\text { GGG AA }\end{array}$ & TCC ACC TGC CCC ACC TG & $\begin{array}{l}\text { This } \\
\text { study }\end{array}$ \\
\hline INS2 & Mouse & $\begin{array}{l}\text { AGG CTC TCT ACC TGG } \\
\text { TGT GT }\end{array}$ & $\begin{array}{l}\text { TCT GAA GGT CAC CTG } \\
\text { CTC CC }\end{array}$ & $\begin{array}{l}\text { This } \\
\text { study }\end{array}$ \\
\hline INS2 & Rat & $\begin{array}{l}\text { AACCATCAGCAAGCAGGT } \\
\text { CA }\end{array}$ & $\begin{array}{l}\text { TCCACCAAGTGAGAACCAC } \\
\text { A }\end{array}$ & $\begin{array}{l}\text { This } \\
\text { study }\end{array}$ \\
\hline Glut2 & Mouse & $\begin{array}{l}\text { AATGGTCGCCTCATTCTTT } \\
\text { G }\end{array}$ & $\begin{array}{l}\text { AGCCAACATTGCTTTGATC } \\
\text { c }\end{array}$ & $\begin{array}{l}\text { This } \\
\text { study }\end{array}$ \\
\hline Glut2 & Rat & $\begin{array}{l}\text { TTGCTCCAACCACACTCA } \\
\text { GG }\end{array}$ & $\begin{array}{l}\text { CTGAGGCCAGCAATCTGA } \\
\text { CT }\end{array}$ & $\begin{array}{l}\text { This } \\
\text { study }\end{array}$ \\
\hline
\end{tabular}




\begin{tabular}{|c|c|c|c|c|}
\hline Glut2 & Human & $\begin{array}{l}\text { TGCCACACTCACACAAGA } \\
\text { CC }\end{array}$ & $\begin{array}{l}\text { AACTGGAAGGAACCCAGC } \\
\text { AC }\end{array}$ & $\begin{array}{l}\text { This } \\
\text { study }\end{array}$ \\
\hline $\mathrm{F} 4 / 80$ & Mouse & $\begin{array}{l}\text { TGACAACCAGACGGCTTG } \\
\text { TG }\end{array}$ & $\begin{array}{l}\text { GCAGGCGAGGAAAAGATA } \\
\text { GTGT }\end{array}$ & $\begin{array}{l}\text { This } \\
\text { study }\end{array}$ \\
\hline CD68 & Human & $\begin{array}{l}\text { CCC CAA CAA AAC CAA } \\
\text { GGT CC }\end{array}$ & $\begin{array}{l}\text { GGA GGT CCT GCA TGA } \\
\text { ATC CAA A }\end{array}$ & $\begin{array}{l}\text { This } \\
\text { study }\end{array}$ \\
\hline TNF- $\alpha$ & Mouse & $\begin{array}{l}\text { CTGTAGCCCACGTCGTAG } \\
\text { C }\end{array}$ & TTGAGATCCATGCCGTTG & $\begin{array}{l}\text { This } \\
\text { study }\end{array}$ \\
\hline TNF- $\alpha$ & Human & $\begin{array}{l}\text { CAGCCTCTTCTCCTTCCTG } \\
\text { AT }\end{array}$ & $\begin{array}{l}\text { GCCAGAGGGCTGATTAGA } \\
\text { GA }\end{array}$ & $\begin{array}{l}\text { This } \\
\text { study }\end{array}$ \\
\hline $\mathrm{IL}-1 \beta$ & Mouse & $\begin{array}{l}\text { GCAACTGTTCCTGAACTC } \\
\text { AACT }\end{array}$ & $\begin{array}{l}\text { ATCTTTTGGGGTCCGTCAA } \\
\text { CT }\end{array}$ & $\begin{array}{l}\text { This } \\
\text { study }\end{array}$ \\
\hline $\mathrm{IL}-1 \beta$ & Rat & $\begin{array}{l}\text { TTTCGACAGTGAGGAGAA } \\
\text { TGACC }\end{array}$ & $\begin{array}{l}\text { CTGGACAGCCCAAGTCAA } \\
\text { GG }\end{array}$ & $\begin{array}{l}\text { This } \\
\text { study }\end{array}$ \\
\hline $\mathrm{IL}-1 \beta$ & Human & $\begin{array}{l}\text { GCT GAG GAA GAT GCT } \\
\text { GGT TC }\end{array}$ & $\begin{array}{l}\text { GTG ATC GTA CAG GTG } \\
\text { CAT CG }\end{array}$ & $\begin{array}{l}\text { This } \\
\text { study }\end{array}$ \\
\hline IL-6 & Mouse & $\begin{array}{l}\text { TCGTGGAAATGAGAAAAG } \\
\text { AGTTGTG }\end{array}$ & $\begin{array}{l}\text { TCCAGTTTGGTAGCATCCA } \\
\text { TCAT }\end{array}$ & $\begin{array}{l}\text { This } \\
\text { study }\end{array}$ \\
\hline TLR2 & Mouse & $\begin{array}{l}\text { TAGGGGCTTCACTTCTCT } \\
\text { GC }\end{array}$ & $\begin{array}{l}\text { CCAAAGAGCTCGTAGCATC } \\
\text { c }\end{array}$ & $\begin{array}{l}\text { This } \\
\text { study }\end{array}$ \\
\hline TLR5 & Mouse & CTGGAGCCGAGTGAGGTC & CGGCAAGCATTGTTCTCC & $\begin{array}{l}\text { This } \\
\text { study }\end{array}$ \\
\hline TLR5 & Human & $\begin{array}{l}\text { GAC ACA ATC TCG GCT } \\
\text { GAC TG }\end{array}$ & $\begin{array}{l}\text { TCA GGA ACA TGA ACA } \\
\text { TCA ATC TG }\end{array}$ & $\begin{array}{l}\text { This } \\
\text { study }\end{array}$ \\
\hline TLR5 & Rat & $\begin{array}{l}\text { GACCCAGTATGCTCGCTT } \\
\text { GA }\end{array}$ & $\begin{array}{l}\text { GATGGGGCAGTCCCTGAA } \\
\text { AA }\end{array}$ & $\begin{array}{l}\text { This } \\
\text { study }\end{array}$ \\
\hline
\end{tabular}


A

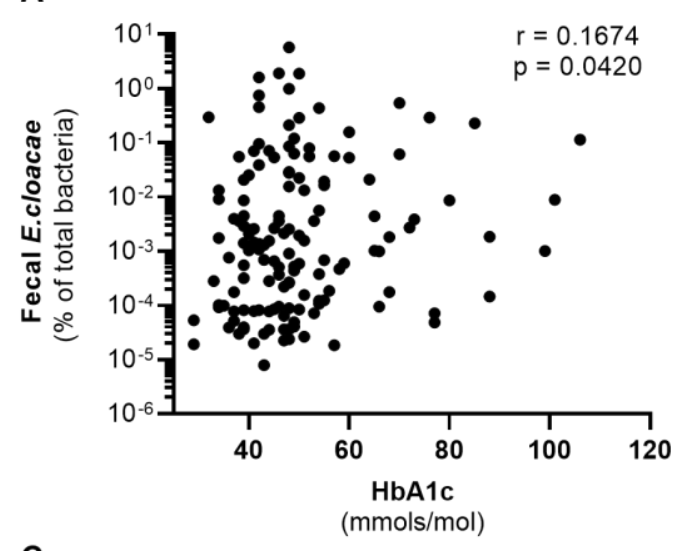

C

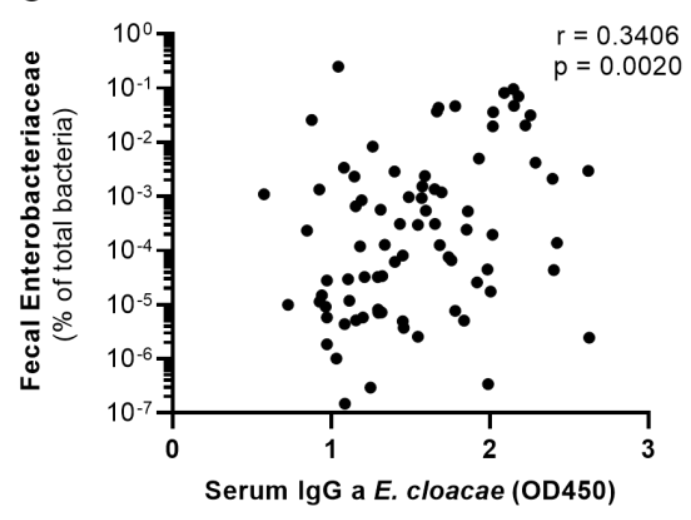

D

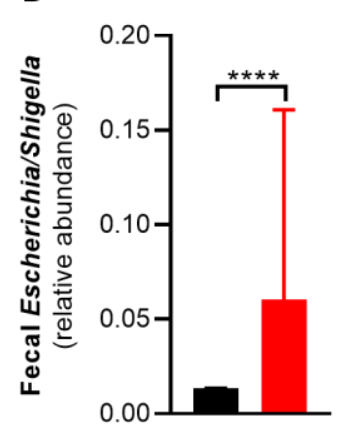

E

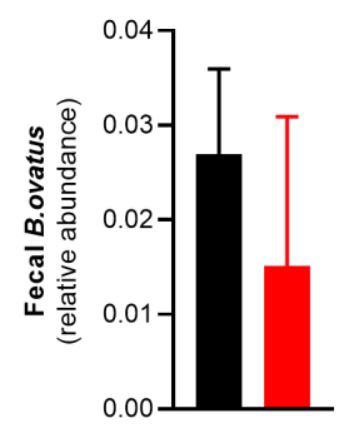

B

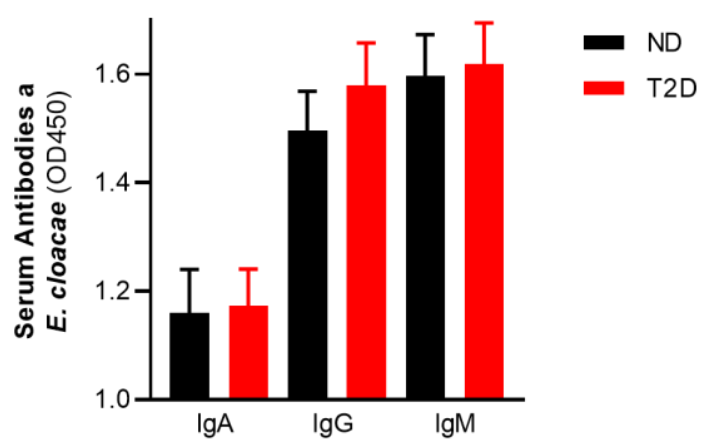

1018

F

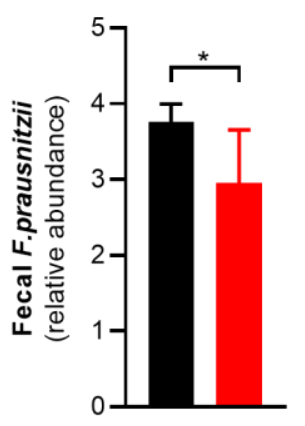

1019 Figure S1. Fecal pathogens are associated with glucose intolerance.

1020 (A) Fecal Enterobacter cloacae positively correlates with glucose marker $\mathrm{HbA} 1 \mathrm{c}$ in a 1021 subset of the HELIUS cohort $(\mathrm{N}=150)$.

1022 (B) Serum antibodies against E. cloacae are not different between ND and T2D in 1023 subset of the HELIUS cohort $(\mathrm{N}=80)$.

1024 (C) Serum IgG anti E.cloacae positively correlates with fecal Enterobacteriaceae $(\mathrm{N}=$ 102580 , Spearman correlation). 
1026 (D) Fecal Escherichia is increased in T2D (HELIUS cohort, $\mathrm{N}=803$ )

1027 (E) Fecal Bacteroides ovatus is non-significantly decreased in T2D (HELIUS cohort, N $1028=803)$

1029 (F) Fecal Fecalibacterium prausnitzii is decreased in T2D (HELIUS cohort, $\mathrm{N}=803$ )

1030 Data shown are mean \pm SEM, except for gut microbiota (median with 95\% confidence 1031 interval). Spearman correlation (A, C) and Mann Whitney test (D, F) was used: $1032{ }^{*} \mathrm{p}<0.05,{ }^{* * *} \mathrm{p}<0.0001$. Abbreviations: ND, no diabetes; T2D, Type 2 diabetes; lgG, 1033 Immunoglobulin G; HbA1c, glycated hemoglobin. 
A

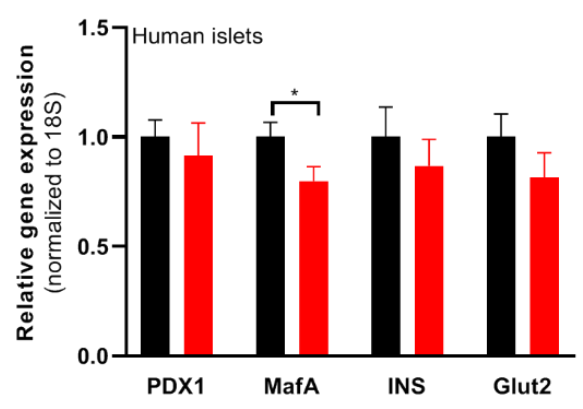

C

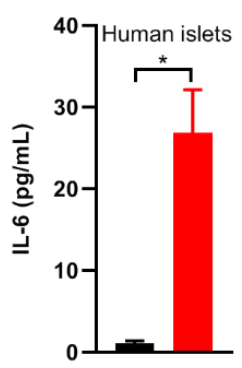

B
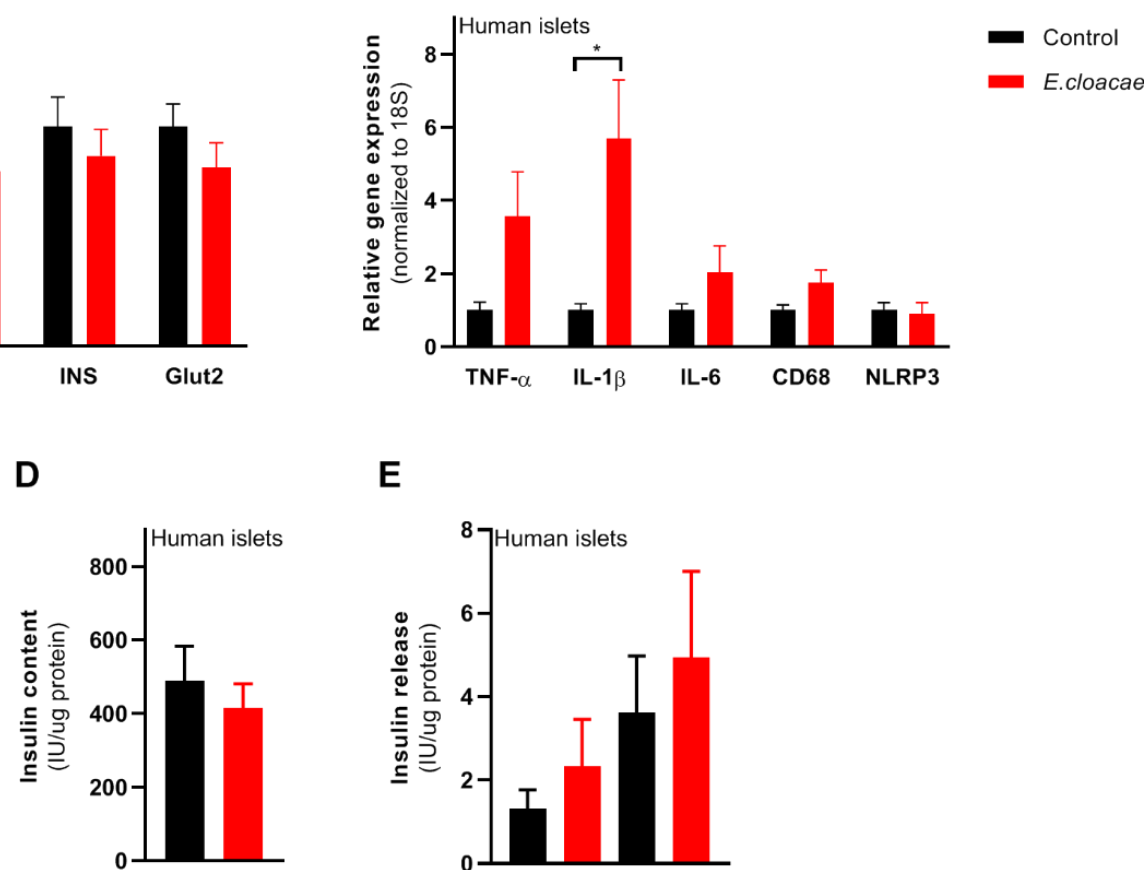

E

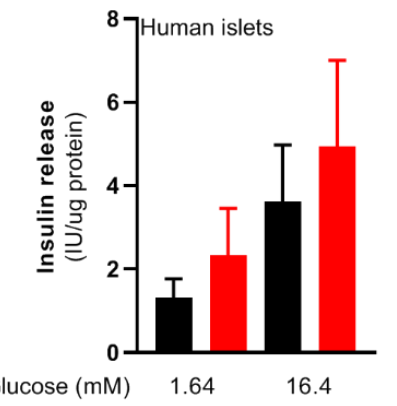

1035

1036 Figure S2. E.cloacae induces beta cell inflammation and partially dysfunction in 1037 human islets.

1038 Human islets were ordered from ProdoLabs and treated with E.cloacae (1E6

1039 CFUs $/ \mathrm{mL})$ for $72 \mathrm{~h}$.

1040 (A) E.cloacae reduces beta cell marker expression in human islets.

1041 (B) E.cloacae induces beta cell inflammation in human islets.

1042 (C) E.cloacae induces IL-6 release from human islets.

1043 (D) E.cloacae slightly reduces insulin content in human islets.

1044 (E) E.cloacae slightly induces insulin hypersecretion in human islets.

1045 Data shown are mean \pm SEM. Unpaired t-test was used for statistical analysis: $1046{ }^{*} p<0.05,{ }^{* \star} p<0.01,{ }^{\star * *} p<0.001,{ }^{* \star *} p<0.0001$.

1047 Abbreviations: INS1 and INS2, insulin 1 and 2; NLRP3, NACHT, LRR and PYD domains-containing protein 3; IL-1 $\beta$, Interleukin 1 beta; IL-6, Interleukin 6; TLR, toll like receptor. 
A

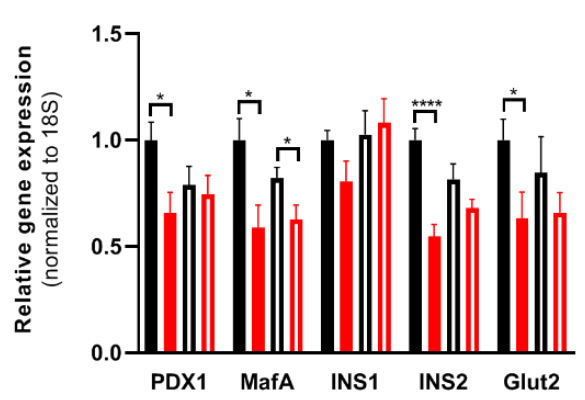

C

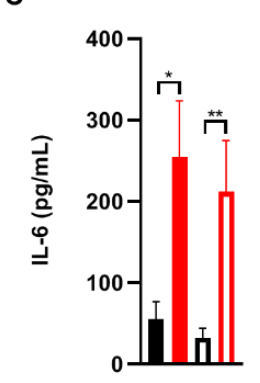

D

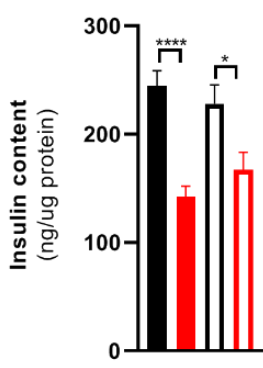

F

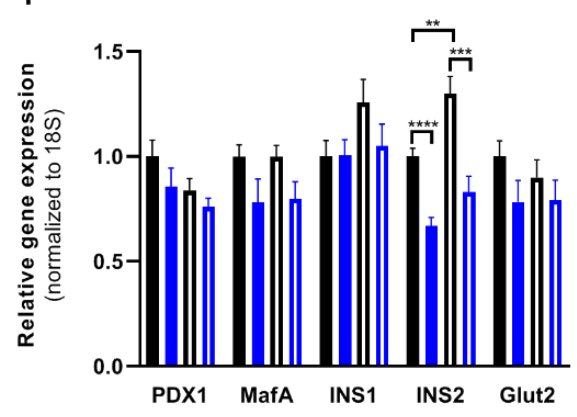

H

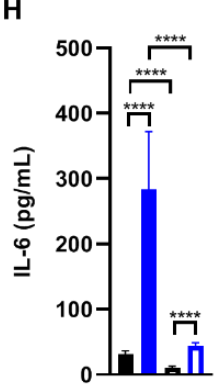

I

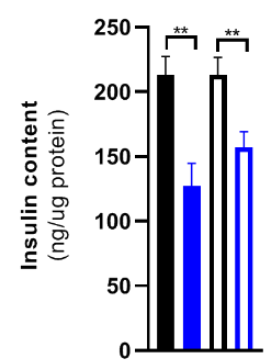

B

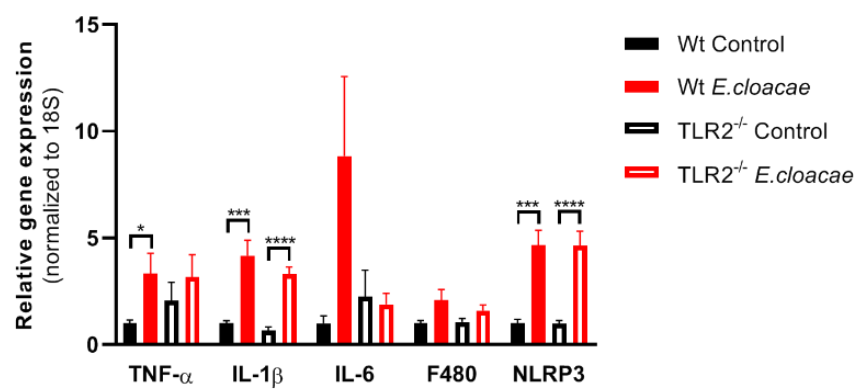

E

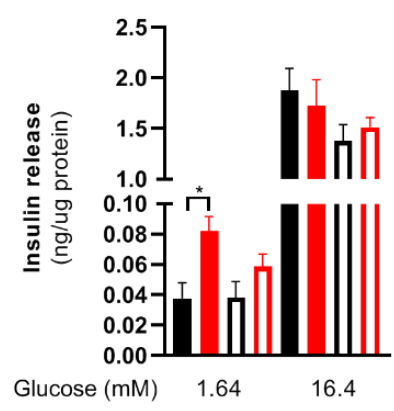

G

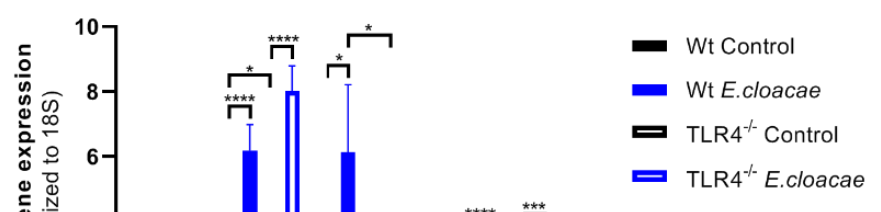

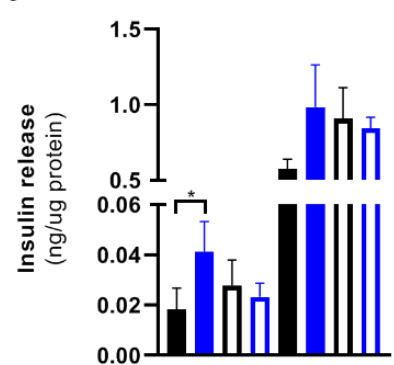

Glucose (mM) $\quad 1.64 \quad 16.4$

Figure S3. TLR2 and TLR4 knock out does not protect from beta cell inflammation and

1055 Freshly isolated pancreatic islets from C57BL6J TLR2 ${ }^{-/-}$(A-E) and TLR4 ${ }^{-/}$(FJ) mice were treated with heat-inactivated Enterobacter cloacae (1E6 CFUs/mL) for $72 \mathrm{~h}$. 
1057 (A) E. cloacae reduces expression of beta-cell genes both in wild-type and TLR2 knock 1058 out pancreatic islets of C57BL6J mice.

1059 (B) E. cloacae increases expression of inflammatory genes in wild-type and TLR2 1060 knock out pancreatic islets of C57BL6J mice.

1061 (C) E. cloacae increases secreted IL-6 from by wild-type and TLR2 knock out 1062 pancreatic islets of C57BL6J mice.

1063 (D) E. cloacae reduces insulin content in wild-type and TLR2 knock out pancreatic 1064 islets of C57BL6J mice.

1065 (E) E. cloacae induces insulin hypersecretion in wild-type and TLR2 knock out 1066 pancreatic islets during low-glucose concentrations of C57BL6J mice.

1067 (F) E. cloacae reduces expression of beta-cell genes both in wild-type and TLR4 knock 1068 out pancreatic islets of C57BL6J mice.

1069 (G) E. cloacae increase expression of inflammatory genes in islets in wild-type and 1070 TLR4 knock out pancreatic islets of C57BL6J mice.

1071 (H) E. cloacae increases secreted IL-6 from by wild-type and TLR4 knock out 1072 pancreatic islets of C57BL6J mice.

1073 (I) E. cloacae reduces insulin content in wild-type and TLR4 knock out pancreatic islets 1074 of C57BL6J mice.

1075 (J) E. cloacae induces insulin hypersecretion at low glucose concentrations in wild1076 type and TLR4 knock out pancreatic islets of C57BL6J mice.

1077 Data shown are mean \pm SEM. Unpaired t-test (A-C, F-H) or Mann-Whitney test (D, E, 1078 I, J) was used for statistical analysis (mean \pm SEM, 3 representative experiments per 1079 panel). Abbreviations: PDX1, pancreatic and duodenal homeobox 1; INS1 and INS2, 1080 insulin 1 and 2; NLRP3, NACHT, LRR and PYD domains-containing protein 3; TNF- $\alpha$, 1081 tumor necrosis factor-alpha; IL-1 $\beta$, Interleukin 1 beta; IL-6, Interleukin 6; TLR2, Toll1082 like receptor 2 . 
A

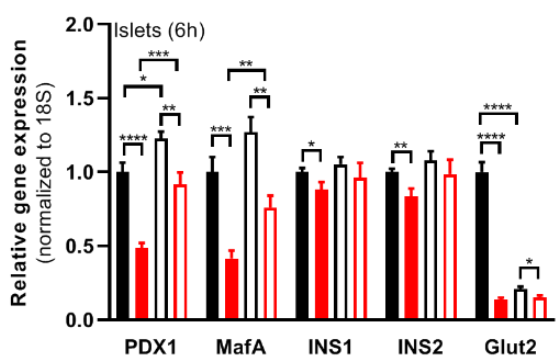

B

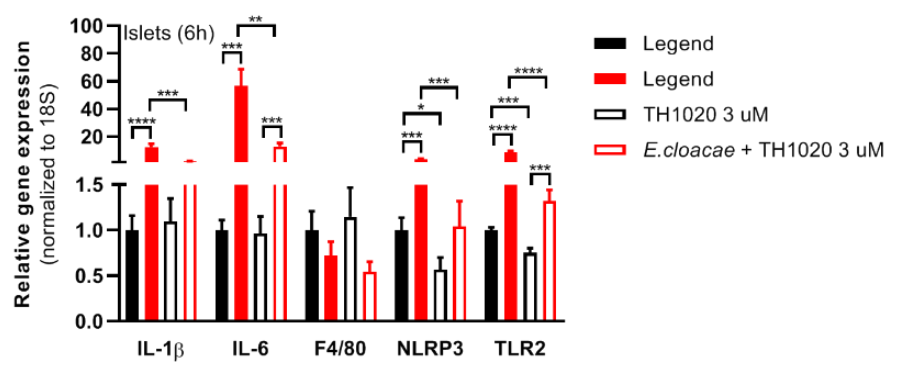

1085 Figure S4. TLR5 inhibitor reduces bacteria induced beta cell dysfunction.

1086 Pancreatic islets were isolated from C57BL6J mice and incubated with TLR5 inhibitor 1087 (3 uM) and E.cloacae (1E6 CFUs $/ \mathrm{mL}$ ) for $6 \mathrm{~h}$.

1088 (A) TLR5 inhibitor TH1020 reverses bacteria induced pancreatic islet dysfunction.

1089 (B) TLR5 inhibitor TH1020 reduces bacteria induced pancreatic islet inflammation.

1090 Data shown are mean \pm SEM. Unpaired t-test was used for statistical analysis: $1091{ }^{*} \mathrm{p}<0.05,{ }^{* *} \mathrm{p}<0.01,{ }^{* * *} \mathrm{p}<0.001,{ }^{* * * *} \mathrm{p}<0.0001$.

1092 Abbreviations: INS1 and INS2, insulin 1 and 2; NLRP3, NACHT, LRR and PYD 1093 domains-containing protein 3; IL-1 $\beta$, Interleukin 1 beta; IL-6, Interleukin 6; TLR, toll like 1094 receptor. 

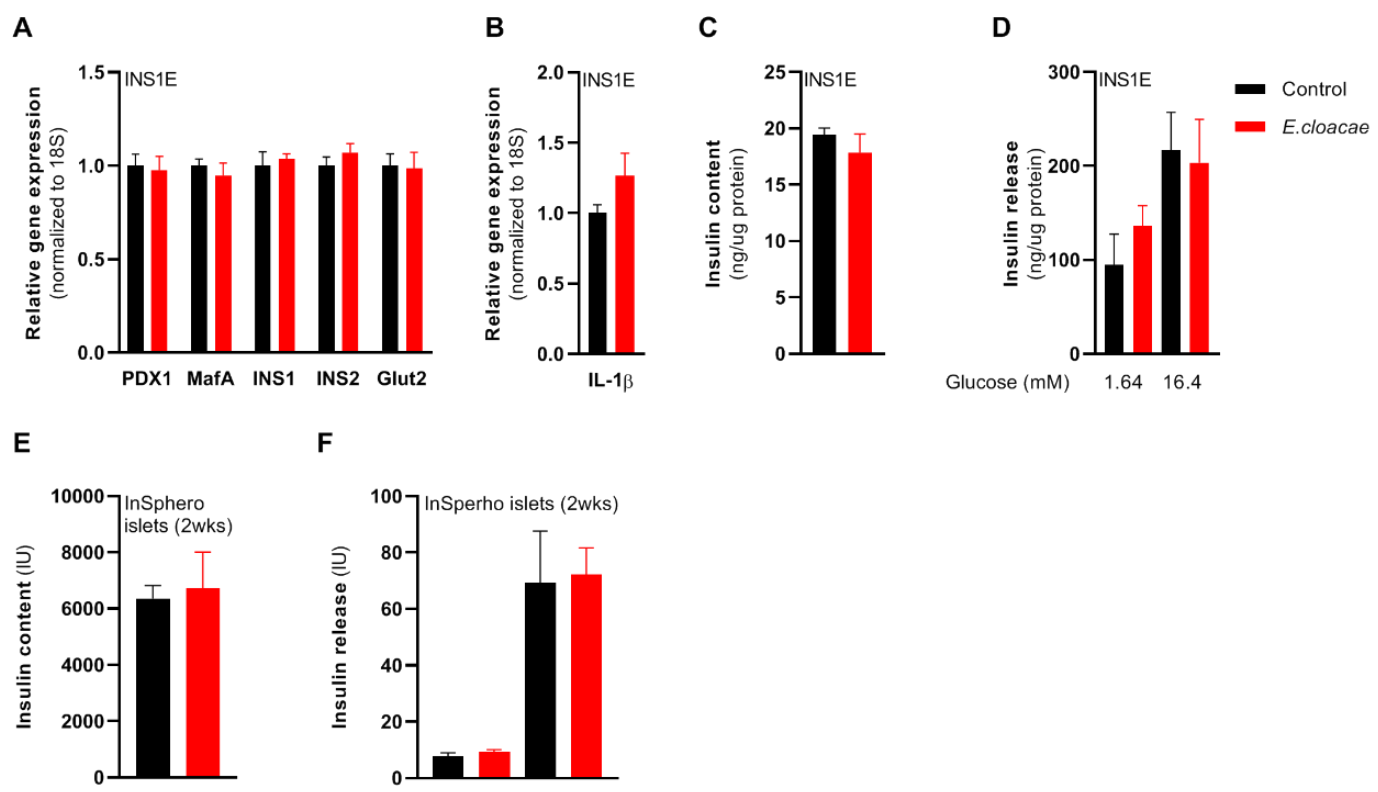

$\mathbf{F}$

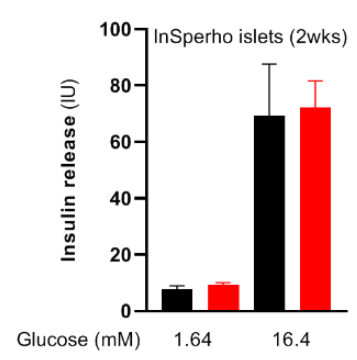

G

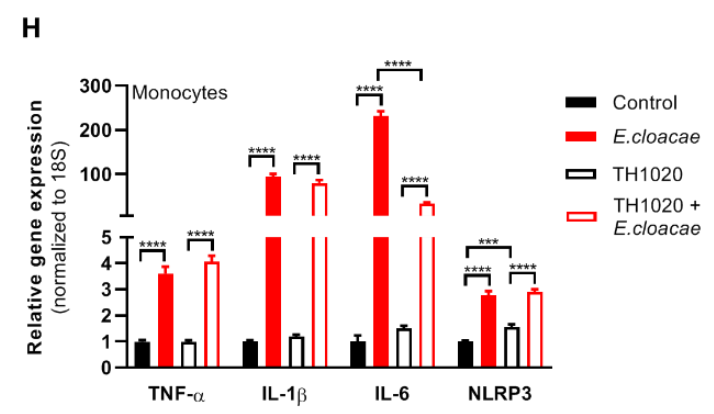

1096

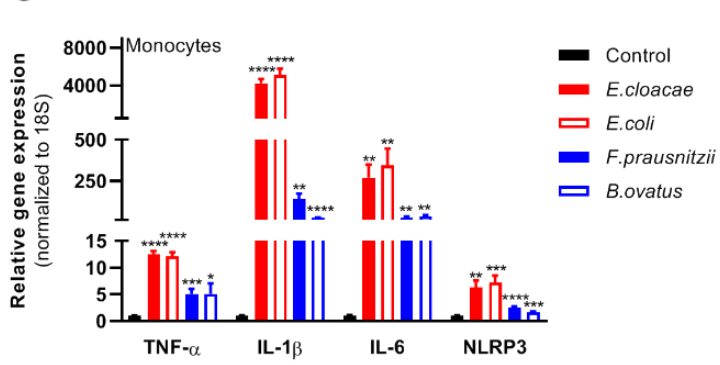

Figure S5. Pure beta cells do no respond to bacteria, but monocytes.

1098 Pure beta cells (INS1E, A-D) and modified human islets without immune cells

1099 (InSphero islets, E-F) were treated with E.cloacae for 72h. Human monocytes were

1100 treated with bacteria (1E6 CFUs/mL) or TLR5 inhibitor TH1020 (3 uM) for 24h (G-H).

1101 (A) E.cloacae does not reduce beta cell marker expression.

1102 (B) E.cloacae does not induce beta cell inflammation.

1103 (C) E.cloacae does not reduce insulin content in beta cells.

1104 (D) E.cloacae does not induce insulin hypersecretion in beta cells.

1105 (E) E.cloacae does not reduce insulin content in InSphero islets.

1106 (F) E.cloacae does not induce insulin hypersecretion in InSphero islets. 
1107 (G) Opportunistic pathogens induce more inflammation than beneficial bacteria in 1108 human monocytes.

1109 (H) TLR5 inhibitor TH1020 reduces IL-6 expression in E.cloacae treated monocytes..

1110 Data shown are mean \pm SEM. Unpaired t-test was used for statistical analysis: $1111{ }^{*} p<0.05,{ }^{* *} p<0.01,{ }^{* * *} p<0.001,{ }^{* * *} p<0.0001$.

1112 Abbreviations: INS1 and INS2, insulin 1 and 2; NLRP3, NACHT, LRR and PYD 1113 domains-containing protein 3; IL-1 $\beta$, Interleukin 1 beta; IL-6, Interleukin 6; TLR, toll like 1114 receptor. 
A

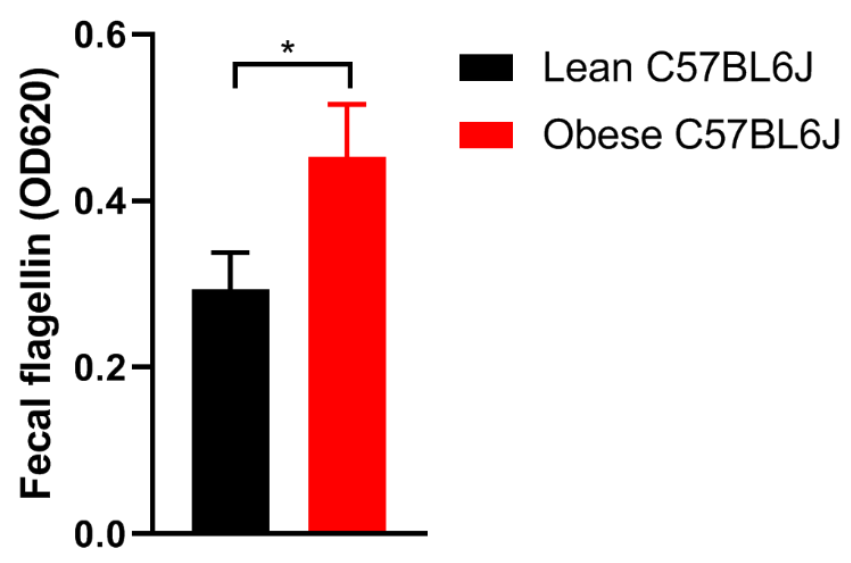

1117 Figure S6. High fat diet feeding increases fecal flagellin content in mice.

1118 C57BL6J mice were on a high fat diet (60\% kcal fat) for 12 weeks. Fecal flagellin was measured in homogenized fecal samples with HEK TLR5 reporter cells.

1120

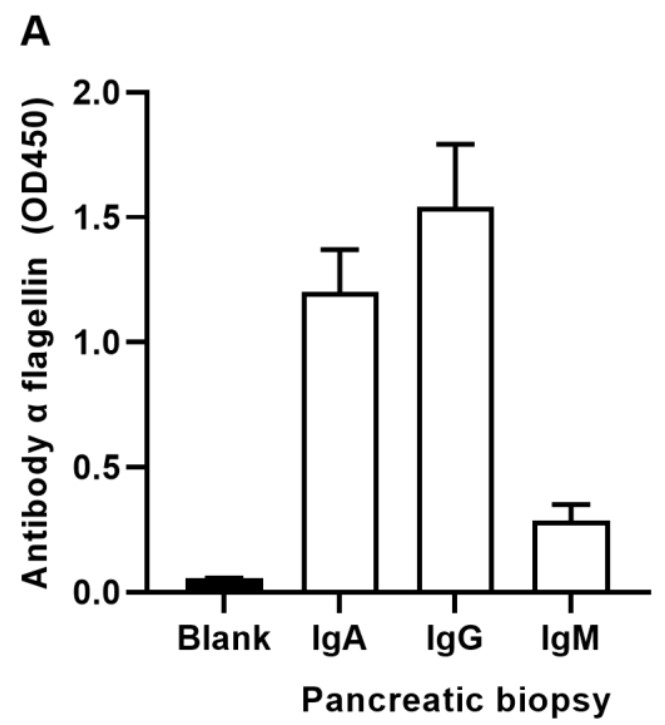

1122 Figure S7. Human pancreatic biopsies harbor antibodies against bacterial 1123 flagellin.

1124 Antibodies against flagellin were measured in homogenates of pancreatic biopsies 1125 from people with T2D undergoing pancreatic surgery. 
A

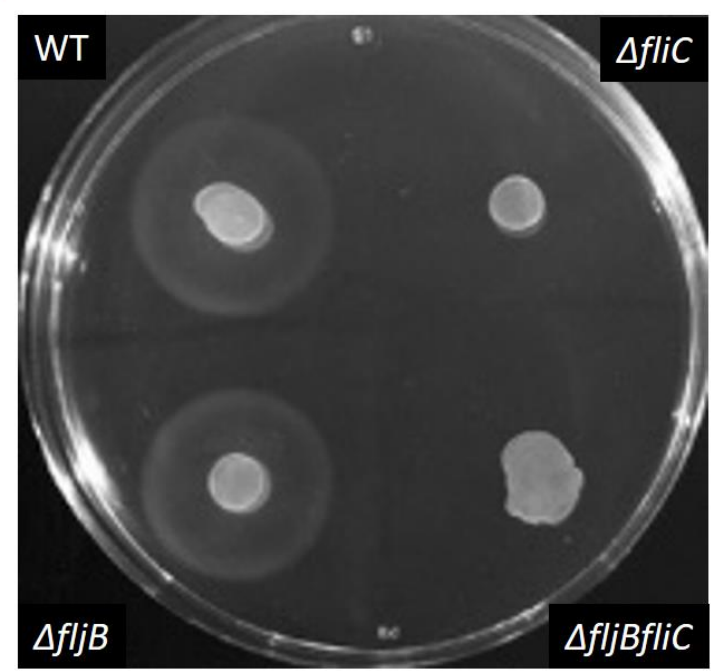

B

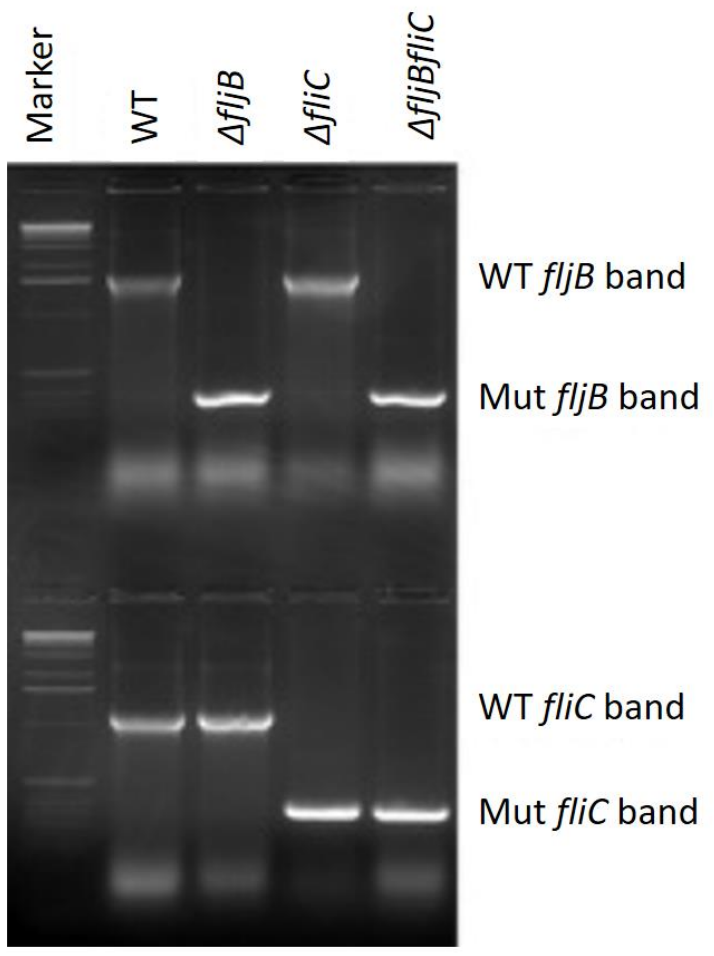

1128 Figure S8. The flagellin gene was deleted in Enterobacter cloacae.

1129 (A) Motility assay and (B) PCR control showing that E.cloacae does not express 1130 flagella. 
1131

1132

1133

1134

1135

1136

1137

1138

1139

1140

1141

1142

1143

1144

1145

1146

1147

1148

1149

1150

1151

1152

1153

1154

1155

1156

1157

1158

1159

1160

1161

1162

1163

1164

1165

1166

\section{References}

Akira, S., and Takeda, K. (2004). Toll-like receptor signalling. Nat Rev Immunol 4, 499-511.

Amar, J., Chabo, C., Waget, A., Klopp, P., Vachoux, C., Bermúdez-Humarán, L.G., Smirnova, N., Bergé, M., Sulpice, T., Lahtinen, S., et al. (2011a). Intestinal mucosal adherence and translocation of commensal bacteria at the early onset of type 2 diabetes: molecular mechanisms and probiotic treatment. EMBO molecular medicine 3, 559-572.

Amar, J., Serino, M., Lange, C., Chabo, C., lacovoni, J., Mondot, S., Lepage, P., Klopp, C., Mariette, J., Bouchez, O., et al. (2011b). Involvement of tissue bacteria in the onset of diabetes in humans: evidence for a concept. Diabetologia 54, 30553061 .

Aykut, B., Pushalkar, S., Chen, R., Li, Q., Abengozar, R., Kim, J.I., Shadaloey, S.A., Wu, D., Preiss, P., Verma, N., et al. (2019). The fungal mycobiome promotes pancreatic oncogenesis via activation of MBL. Nature 574, 264-267.

Boni-Schnetzler, M., and Meier, D.T. (2019). Islet inflammation in type 2 diabetes. Semin Immunopathol 41, 501-513.

Bonifield, H.R., and Hughes, K.T. (2003). Flagellar phase variation in Salmonella enterica is mediated by a posttranscriptional control mechanism. J Bacteriol 185 , 3567-3574.

Brereton, M.F., Iberl, M., Shimomura, K., Zhang, Q., Adriaenssens, A.E., Proks, P., Spiliotis, II, Dace, W., Mattis, K.K., Ramracheya, R., et al. (2014). Reversible changes in pancreatic islet structure and function produced by elevated blood glucose. Nat Commun 5, 4639.

Brissova, M., and Powers, A.C. (2008). Revascularization of transplanted islets: can it be improved? Diabetes $57,2269-2271$.

Cantley, J., and Ashcroft, F.M. (2015). Q\&A: insulin secretion and type 2 diabetes: why do $\beta$-cells fail? BMC Biol 13, 33-33.

Costea, P.I., Zeller, G., Sunagawa, S., Pelletier, E., Alberti, A., Levenez, F., Tramontano, M., Driessen, M., Hercog, R., Jung, F.-E., et al. (2017). Towards standards for human fecal sample processing in metagenomic studies. Nature Biotechnology 35, 1069-1076.

Cullender, T.C., Chassaing, B., Janzon, A., Kumar, K., Muller, C.E., Werner, J.J., Angenent, L.T., Bell, M.E., Hay, A.G., Peterson, D.A., et al. (2013a). Innate and adaptive immunity interact to quench microbiome flagellar motility in the gut. Cell Host Microbe 14, 571-581. 
1167 Cullender, T.C., Chassaing, B., Janzon, A., Kumar, K., Muller, C.E., Werner, J.J., Angenent, L.T., Bell, M.E., Hay, A.G., Peterson, D.A., et al. (2013b). Innate and adaptive immunity interact to quench microbiome flagellar motility in the gut. Cell Host Microbe 14, 571-581.

de Goffau, M.C., Lager, S., Sovio, U., Gaccioli, F., Cook, E., Peacock, S.J., Parkhill, J., Charnock-Jones, D.S., and Smith, G.C.S. (2019). Human placenta has no microbiome but can contain potential pathogens. Nature 572, 329-334.

De Maayer, P., and Cowan, D.A. (2016). Flashy flagella: flagellin modification is relatively common and highly versatile among the Enterobacteriaceae. BMC Genomics 17, 377-377.

Defronzo, R.A. (2009). Banting Lecture. From the triumvirate to the ominous octet: a new paradigm for the treatment of type 2 diabetes mellitus. Diabetes 58, 773-795.

1179 Dehoux, P., Marvaud, J.C., Abouelleil, A., Earl, A.M., Lambert, T., and Dauga, C. (2016). Comparative genomics of Clostridium bolteae and Clostridium clostridioforme reveals species-specific genomic properties and numerous putative antibiotic resistance determinants. BMC Genomics 17, 819.

Deschasaux, M., Bouter, K.E., Prodan, A., Levin, E., Groen, A.K., Herrema, H., Tremaroli, V., Bakker, G.J., Attaye, I., Pinto-Sietsma, S.J., et al. (2018). Depicting the composition of gut microbiota in a population with varied ethnic origins but shared geography. Nat Med 24, 1526-1531. inflammation impairs the pancreatic beta-cell in type 2 diabetes. Physiology (Bethesda) 24, 325-331.

Ellingsgaard, H., Hauselmann, I., Schuler, B., Habib, A.M., Baggio, L.L., Meier, D.T., Eppler, E., Bouzakri, K., Wueest, S., Muller, Y.D., et al. (2011). Interleukin-6 enhances insulin secretion by increasing glucagon-like peptide-1 secretion from $\mathrm{L}$ cells and alpha cells. Nat Med 17, 1481-1489.

1199 Erion, K., and Corkey, B.E. (2018). $\beta$-Cell Failure or $\beta$-Cell Abuse? Front Endocrinol 1200 (Lausanne) 9, 532. 
1201 Esser, N., Utzschneider, K.M., and Kahn, S.E. (2020). Early beta cell dysfunction vs insulin hypersecretion as the primary event in the pathogenesis of dysglycaemia. Diabetologia 63, 2007-2021.

Fei, N., and Zhao, L. (2013). An opportunistic pathogen isolated from the gut of an obese human causes obesity in germfree mice. ISME J 7, 880-884.

Gewirtz, A.T., Simon, P.O., Jr., Schmitt, C.K., Taylor, L.J., Hagedorn, C.H., O'Brien, A.D., Neish, A.S., and Madara, J.L. (2001). Salmonella typhimurium translocates flagellin across intestinal epithelia, inducing a proinflammatory response. J Clin Invest 107, 99-109. Chylomicrons promote intestinal absorption of lipopolysaccharides. J Lipid Res 50, 90-97.

Giarratana, N., Penna, G., Amuchastegui, S., Mariani, R., Daniel, K.C., and Adorini, Production by Pancreatic Islets Inhibiting T Cell Recruitment and Type 1 Diabetes Development. The Journal of Immunology 173, 2280.

Gomes, J.M.G., Costa, J.A., and Alfenas, R.C.G. (2017). Metabolic endotoxemia and diabetes mellitus: A systematic review. Metabolism 68, 133-144.

1219 Gurung, M., Li, Z., You, H., Rodrigues, R., Jump, D.B., Morgun, A., and Shulzhenko, N. (2020). Role of gut microbiota in type 2 diabetes pathophysiology. EBioMedicine 51, 102590-102590.

1222 Haiko, J., and Westerlund-Wikström, B. (2013). The role of the bacterial flagellum in adhesion and virulence. Biology (Basel) 2, 1242-1267.

Hajmrle, C., Smith, N., Spigelman, A.F., Dai, X., Senior, L., Bautista, A., Ferdaoussi, M., and MacDonald, P.E. (2016). Interleukin-1 signaling contributes to acute islet compensation. JCl Insight 1, e86055.

1227 Hasnain, S.Z., Borg, D.J., Harcourt, B.E., Tong, H., Sheng, Y.H., Ng, C.P., Das, I., Wang, R., Chen, A.C.H., Loudovaris, T., et al. (2014). Glycemic control in diabetes is restored by therapeutic manipulation of cytokines that regulate beta cell stress.

1231 Henquin, J.-C. (2019). The challenge of correctly reporting hormones content and secretion in isolated human islets. Molecular Metabolism 30, 230-239.

1233 Herrema, H., and Niess, J.H. (2020). Intestinal microbial metabolites in human 1234 metabolism and type 2 diabetes. Diabetologia 63, 2533-2547. 
Ho, S.N., Hunt, H.D., Horton, R.M., Pullen, J.K., and Pease, L.R. (1989). Sitedirected mutagenesis by overlap extension using the polymerase chain reaction. Gene 77, 51-59.

Hug, H., Mohajeri, M.H., and La Fata, G. (2018). Toll-Like Receptors: Regulators of the Immune Response in the Human Gut. Nutrients 10, 203.

Igoillo-Esteve, M., Marselli, L., Cunha, D.A., Ladrière, L., Ortis, F., Grieco, F.A., Dotta, F., Weir, G.C., Marchetti, P., Eizirik, D.L., et al. (2010). Palmitate induces a pro-inflammatory response in human pancreatic islets that mimics CCL2 expression by beta cells in type 2 diabetes. Diabetologia 53, 1395-1405.

lyer, S.S., Pulskens, W.P., Sadler, J.J., Butter, L.M., Teske, G.J., Ulland, T.K., Eisenbarth, S.C., Florquin, S., Flavell, R.A., Leemans, J.C., et al. (2009). Necrotic cells trigger a sterile inflammatory response through the Nlrp3 inflammasome. Proc Natl Acad Sci U S A 106, 20388-20393.

Ji, Y., Sun, S., Shrestha, N., Darragh, L.B., Shirakawa, J., Xing, Y., He, Y., Carboneau, B.A., Kim, H., An, D., et al. (2019). Toll-like receptors TLR2 and TLR4 block the replication of pancreatic $\beta$ cells in diet-induced obesity. Nature Immunology 20, 677-686.

Johnson, J.D. (2021). On the causal relationships between hyperinsulinaemia, insulin resistance, obesity and dysglycaemia in type 2 diabetes. Diabetologia 64, 21382146.

Kajikawa, A., Midorikawa, E., Masuda, K., Kondo, K., Irisawa, T., Igimi, S., and Okada, S. (2016). Characterization of flagellins isolated from a highly motile strain of Lactobacillus agilis. BMC Microbiol 16, 49.

Keskitalo, A., Munukka, E., Toivonen, R., Hollmen, M., Kainulainen, H., Huovinen, P., Jalkanen, S., and Pekkala, S. (2018). Enterobacter cloacae administration induces hepatic damage and subcutaneous fat accumulation in high-fat diet fed mice. PLoS One 13, e0198262.

Kootte, R.S., Levin, E., Salojarvi, J., Smits, L.P., Hartstra, A.V., Udayappan, S.D., Hermes, G., Bouter, K.E., Koopen, A.M., Holst, J.J., et al. (2017). Improvement of Insulin Sensitivity after Lean Donor Feces in Metabolic Syndrome Is Driven by Baseline Intestinal Microbiota Composition. Cell Metab 26, 611-619 e616.

Kozich, J.J., Westcott, S.L., Baxter, N.T., Highlander, S.K., and Schloss, P.D. (2013). Development of a dual-index sequencing strategy and curation pipeline for analyzing amplicon sequence data on the MiSeq Illumina sequencing platform. Appl Environ Microbiol 79, 5112-5120. 
1270 Le Chatelier, E., Nielsen, T., Qin, J., Prifti, E., Hildebrand, F., Falony, G., Almeida, 1271 M., Arumugam, M., Batto, J.M., Kennedy, S., et al. (2013). Richness of human gut 1272 microbiome correlates with metabolic markers. Nature 500, 541-546.

1273 Maedler, K., Spinas, G.A., Lehmann, R., Sergeev, P., Weber, M., Fontana, A., 1274 Kaiser, N., and Donath, M.Y. (2001). Glucose induces beta-cell apoptosis via 1275 upregulation of the Fas receptor in human islets. Diabetes 50, 1683-1690.

1276 Marchetti, P. (2016). Islet inflammation in type 2 diabetes. Diabetologia 59, 668-672.

1277 Massier, L., Chakaroun, R., Tabei, S., Crane, A., Didt, K.D., Fallmann, J., von

1278 Bergen, M., Haange, S.-B., Heyne, H., Stumvoll, M., et al. (2020). Adipose tissue 1279 derived bacteria are associated with inflammation in obesity and type 2 diabetes. Gut $1280 \quad 69,1796$.

1281 Matsuda, K., Tsuji, H., Asahara, T., Kado, Y., and Nomoto, K. (2007). Sensitive quantitative detection of commensal bacteria by rRNA-targeted reverse transcriptionPCR. Appl Environ Microbiol 73, 32-39.

Mehran, A.E., Templeman, N.M., Brigidi, G.S., Lim, G.E., Chu, K.Y., Hu, X., Botezelli, J.D., Asadi, A., Hoffman, B.G., Kieffer, T.J., et al. (2012). Hyperinsulinemia drives diet-induced obesity independently of brain insulin production. Cell Metab 16, 723737. Lactobacillus ruminis strains cluster according to their mammalian gut source. BMC Microbiol 15, 80.

Nackiewicz, D., Dan, M., He, W., Kim, R., Salmi, A., Rütti, S., Westwell-Roper, C., Cunningham, A., Speck, M., Schuster-Klein, C., et al. (2014). TLR2/6 and TLR4activated macrophages contribute to islet inflammation and impair beta cell insulin gene expression via IL-1 and IL-6. Diabetologia 57, 1645-1654.

Nackiewicz, D., Dan, M., Speck, M., Chow, S.Z., Chen, Y.-C., Pospisilik, J.A., State following Pancreatic Beta-Cell Death and Are a Major Source of Islet Insulinlike Growth Factor-1. iScience 23, 100775.

1299 Nadkarni, M.A., Martin, F.E., Jacques, N.A., and Hunter, N. (2002). Determination of 1300 bacterial load by real-time PCR using a broad-range (universal) probe and primers 1301 set. Microbiology (Reading) 148, 257-266.

1302 Ouchi, N., Parker, J.L., Lugus, J.J., and Walsh, K. (2011). Adipokines in inflammation 
1304

Pories, W.J., and Dohm, G.L. (2012). Diabetes: have we got it all wrong? Hyperinsulinism as the culprit: surgery provides the evidence. Diabetes Care 35, 2438-2442.

Qin, J., Li, Y., Cai, Z., Li, S., Zhu, J., Zhang, F., Liang, S., Zhang, W., Guan, Y., Shen, D., et al. (2012). A metagenome-wide association study of gut microbiota in type 2 diabetes. Nature 490, 55-60.

Rahier, J., Guiot, Y., Goebbels, R.M., Sempoux, C., and Henquin, J.C. (2008). Pancreatic $\beta$-cell mass in European subjects with type 2 diabetes. Diabetes, Obesity and Metabolism 10, 32-42.

Riquelme, E., Zhang, Y., Zhang, L., Montiel, M., Zoltan, M., Dong, W., Quesada, P., Sahin, I., Chandra, V., San Lucas, A., et al. (2019). Tumor Microbiome Diversity and Composition Influence Pancreatic Cancer Outcomes. Cell 178, 795-806.e712.

Rogers, M.B., Aveson, V., Firek, B., Yeh, A., Brooks, B., Brower-Sinning, R., Steve, J., Banfield, J.F., Zureikat, A., Hogg, M., et al. (2017). Disturbances of the Perioperative Microbiome Across Multiple Body Sites in Patients Undergoing Pancreaticoduodenectomy. Pancreas 46, 260-267.

Rosengren, A.H., Braun, M., Mahdi, T., Andersson, S.A., Travers, M.E., Shigeto, M., Zhang, E., Almgren, P., Ladenvall, C., Axelsson, A.S., et al. (2012). Reduced insulin exocytosis in human pancreatic $\beta$-cells with gene variants linked to type 2 diabetes. Diabetes 61, 1726-1733.

Scheithauer, T.P.M., Bakker, G.J., Winkelmeijer, M., Davids, M., Nieuwdorp, M., van Raalte, D.H., and Herrema, H. (2021). Compensatory intestinal immunoglobulin response after vancomycin treatment in humans. Gut Microbes 13, 1-14.

Scheithauer, T.P.M., Rampanelli, E., Nieuwdorp, M., Vallance, B.A., Verchere, C.B., van Raalte, D.H., and Herrema, H. (2020). Gut Microbiota as a Trigger for Metabolic Inflammation in Obesity and Type 2 Diabetes. Frontiers in Immunology 11.

Snijder, M.B., Galenkamp, H., Prins, M., Derks, E.M., Peters, R.J.G., Zwinderman, A.H., and Stronks, K. (2017). Cohort profile: the Healthy Life in an Urban Setting (HELIUS) study in Amsterdam, The Netherlands. BMJ Open 7, e017873.

Staimez, L.R., Weber, M.B., Ranjani, H., Ali, M.K., Echouffo-Tcheugui, J.B., Phillips, L.S., Mohan, V., and Narayan, K.M.V. (2013). Evidence of Reduced $\beta$-Cell Function in Asian Indians With Mild Dysglycemia. Diabetes Care 36, 2772-2778.

Takeuchi, O., Hoshino, K., Kawai, T., Sanjo, H., Takada, H., Ogawa, T., Takeda, K., and Akira, S. (1999). Differential Roles of TLR2 and TLR4 in Recognition of GramNegative and Gram-Positive Bacterial Cell Wall Components. Immunity 11, 443-451. 
1339 Tamanai-Shacoori, Z., Smida, I., Bousarghin, L., Loreal, O., Meuric, V., Fong, S.B., 1340 Bonnaure-Mallet, M., and Jolivet-Gougeon, A. (2017). Roseburia spp.: a marker of 1341 health? Future Microbiol 12, 157-170.

1342 Templeman, N.M., Clee, S.M., and Johnson, J.D. (2015). Suppression of hyperinsulinaemia in growing female mice provides long-term protection against obesity. Diabetologia 58, 2392-2402.

Templeman, N.M., Flibotte, S., Chik, J.H.L., Sinha, S., Lim, G.E., Foster, L.J., Nislow, C., and Johnson, J.D. (2017). Reduced Circulating Insulin Enhances Insulin Sensitivity in Old Mice and Extends Lifespan. Cell Rep 20, 451-463.

Thomas, R.M., and Jobin, C. (2020). Microbiota in pancreatic health and disease: the next frontier in microbiome research. Nature Reviews Gastroenterology \& Hepatology 17, 53-64.

1351 Ting, S.Y., Martínez-García, E., Huang, S., Bertolli, S.K., Kelly, K.A., Cutler, K.J., Su, E.D., Zhi, H., Tang, Q., Radey, M.C., et al. (2020). Targeted Depletion of Bacteria from Mixed Populations by Programmable Adhesion with Antagonistic Competitor Cells. Cell Host Microbe 28, 313-321.e316.

Tran, H.Q., Ley, R.E., Gewirtz, A.T., and Chassaing, B. (2019). Flagellin-elicited adaptive immunity suppresses flagellated microbiota and vaccinates against chronic inflammatory diseases. Nature Communications 10, 5650.

Tricò, D., Natali, A., Arslanian, S., Mari, A., and Ferrannini, E. (2018). Identification, pathophysiology, and clinical implications of primary insulin hypersecretion in nondiabetic adults and adolescents. JCI Insight 3.

1361 Udayappan, S.D., Kovatcheva-Datchary, P., Bakker, G.J., Havik, S.R., Herrema, H., Cani, P.D., Bouter, K.E., Belzer, C., Witjes, J.J., Vrieze, A., et al. (2017). Intestinal Ralstonia pickettii augments glucose intolerance in obesity. PLOS ONE 12, e0181693.

Van Olden, C.C., Van de Laar, A.W., Meijnikman, A.S., Aydin, O., Van Olst, N., Hoozemans, J.B., De Brauw, L.M., Bruin, S.C., Acherman, Y.I.Z., Verheij, J., et al. (2021). A systems biology approach to understand gut microbiota and host metabolism in morbid obesity: design of the BARIA Longitudinal Cohort Study. J Intern Med 289, 340-354. diabetes: Stimulate insulin secretion or provide beta-cell rest? Diabetes Obes Metab $19,1205-1213$.

1373 Vijay-Kumar, M., and Gewirtz, A.T. (2009). Flagellin: key target of mucosal innate immunity. Mucosal Immunol 2, 197-205. 
1375 Wen, L., Peng, J., Li, Z., and Wong, F.S. (2004). The effect of innate immunity on autoimmune diabetes and the expression of Toll-like receptors on pancreatic islets. $J$ Immunol 172, 3173-3180.

1378 Westwell-Roper, C.Y., Ehses, J.A., and Verchere, C.B. (2014). Resident macrophages mediate islet amyloid polypeptide-induced islet IL-1 $\beta$ production and $\beta$ cell dysfunction. Diabetes 63, 1698-1711.

1381 Weyer, C., Bogardus, C., Mott, D.M., and Pratley, R.E. (1999). The natural history of insulin secretory dysfunction and insulin resistance in the pathogenesis of type 2 diabetes mellitus. J Clin Invest 104, 787-794.

1384 Weyer, C., Funahashi, T., Tanaka, S., Hotta, K., Matsuzawa, Y., Pratley, R.E., and Tataranni, P.A. (2001). Hypoadiponectinemia in Obesity and Type 2 Diabetes: Close Association with Insulin Resistance and Hyperinsulinemia. The Journal of Clinical Endocrinology \& Metabolism 86, 1930-1935.

Weyer, C., Hanson, R.L., Tataranni, P.A., Bogardus, C., and Pratley, R.E. (2000). A high fasting plasma insulin concentration predicts type 2 diabetes independent of insulin resistance: evidence for a pathogenic role of relative hyperinsulinemia. Diabetes 49, 2094-2101. obesity-associated islet inflammation and $\beta$-cell abnormalities. Nature Reviews Endocrinology 16, 81-90.

Ying, W., Lee, Y.S., Dong, Y., Seidman, J.S., Yang, M., Isaac, R., Seo, J.B., Yang, B.H., Wollam, J., Riopel, M., et al. (2019). Expansion of Islet-Resident Macrophages Leads to Inflammation Affecting $\beta$ Cell Proliferation and Function in Obesity. Cell

1398 Metab 29, 457-474.e455.

1399 Yoon, S.-i., Kurnasov, O., Natarajan, V., Hong, M., Gudkov, A.V., Osterman, A.L., and Wilson, I.A. (2012). Structural basis of TLR5-flagellin recognition and signaling. Science 335, 859-864.

Zhang, M., Chekan, J.R., Dodd, D., Hong, P.-Y., Radlinski, L., Revindran, V., Nair, S.K., Mackie, R.I., and Cann, I. (2014). Xylan utilization in human gut commensal bacteria is orchestrated by unique modular organization of polysaccharide-degrading 